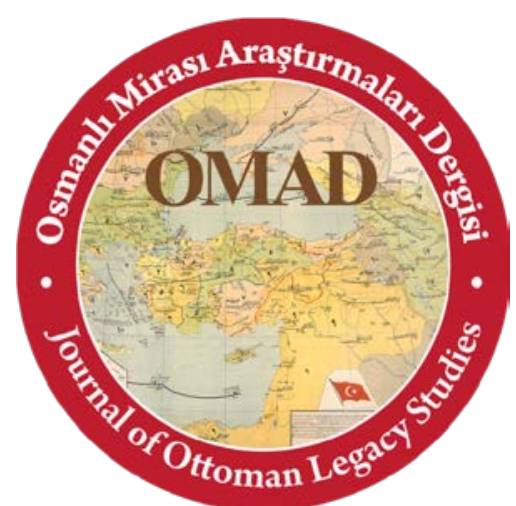

Osmanlı Mirası Araştırmaları Dergisi / Journal of Ottoman Legacy Studies

ISSN 2148-5704

www.osmanlimirasi.net

osmanlimirasi@gmail.com

Cilt 7, Sayı 19, Kasım 2020 / Volume 7, Issue 19, November 2020

\title{
OSMANLI TOPLUMUNDA UYUŞTURUCU MADDE KULLANIMI VE DEVLETIN BUNA KARŞI BAZI MÜCADELE ÇALIŞMALARI
}

Drug Use in the Ottoman Society and State's Some Struggle Studies Against It

\author{
Makale Türü/Article Types : Araştırma Makalesi/Research Article \\ Geliş Tarihi/Received Date : 27.08 .2020 \\ Kabul Tarihi/Accepted Date : 26.10 .2020 \\ Sayfa/Pages : 627-654 \\ DOI Numaras1/DOI Number $\quad$ : http://dx.doi.org/10.17822/omad.2020.174
}

\section{Kaya GÖKTEPE}

(Dr. Öğr. Üyesi), İstanbul Medeniyet Üniversitesi, Siyasal Bilgiler Fakültesi, İktisat Bölümü, İstanbul / Türkiye, e-mail: kayagoktepe@yahoo.com, ORCID: https:/ /orcid.org/0000-0002-

\section{Atif/Citation}

Göktepe, Kaya, “Osmanlı Toplumunda Uyuşturucu Madde Kullanımı ve Devletin Buna Karşı Bazı Mücadele Çalışmaları", Osmanlı Mirası Araştırmaları Dergisi, 7/19, 2020, s. 627-654. 



\title{
OSMANLI TOPLUMUNDA UYUŞTURUCU MADDE KULLANIMI VE DEVLETIN BUNA KARŞI BAZI MÜCADELE ÇALIŞMALARI
}

\author{
Drug Use in the Ottoman Society and State's Some Struggle Studies Against It
}

\section{Kaya GÖKTEPE}

Öz: Uyuşturucu madde, insanlık tarihi boyunca toplumları ve devletleri yakından ilgilendiren bir mesele olarak varlık göstermiştir. Uyuşturucu maddeler içerisinde ise özellikle afyon ve esrar, İlk Çağ toplumlarından itibaren sağlık alanında tedavi edici özellikleri yanında keyif amacıyla kullanılan ürünler olarak dikkat çekmiş olup uyuşturucu maddeler içerisinde özellikle afyon ve esrarın keyif amacıyla kullanımı, Türk İslam toplumları için de geçerliliğini korumuştur. Aynı şekilde Osmanlı toplumunda da keyif verici madde kullanımları içerisinde afyon ve esrar, en sık kullanılan uyuşturucular olarak kendini göstermiştir. Osmanlı döneminde afyon, esrar ve türevleri, sağlık alanında tedavi amacıyla kullanılan ürünler olarak tanındığı için ilgili esnaf grupları tarafından piyasaya rahatlıkla arz edilen mallar kategorisinde yer almıştır. Bu mallar her ne kadar sağlık ürünü olarak piyasaya arz edilse de amacı dışında keyif için kullanıldığında insan sağlığını olumsuz etkilemektedir. Bundan dolayı mesele, toplumu ilgilendiren bir halk sağlığı problemi olarak görüldüğünden, bu süreçte devlete düşen rol de kendiliğinden artmıştır. Osmanlı toplumunda keyif amacıyla uyuşturucu madde kullanımı ve devletin buna karşı mücadele stratejisini tahlil etmeyi amaçlayan bu araştırma, Osmanlı toplumunu etkileyen uyuşturucu madde kullanımının genel durumu ile toplumun ve devletin uyuşturucu maddeye karşı bakış açısını ortaya koymayı hedeflemektedir. Bunun için de uyuşturucu maddenin keyif amacıyla kullanılması hâlinde toplumda ve insan sağlığında açtığı sorunlar ile devletin hukuk, idare, iktisat ve sağlık gibi alanlardaki mücadele çalışmaları, Osmanlı devlet sisteminin bütüncül yapısı çerçevesinde ele alınmaya çalışılmaktadır.

Anahtar Kelimeler: Uyuşturucu, bağımlılık, afyon, esrar, Osmanlı

Abstract: Drugs have existed as an issue that closely concerns societies and states throughout human history. Among the narcotic substances, opium and cannabis have attracted attention as the products used for pleasure as well as therapeutic properties in the field of health since the ancient societies, and the use of opium and cannabis for pleasure in drugs has also been valid for Turkish-Islamic societies. In the same way, opium and cannabis have shown themselves as the most frequently used drugs among the enjoyable substance uses in the Ottoman society. Since opium, cannabis and its derivatives were recognized as products used in the field of health in the Ottoman period, they were included in the category of goods that can be easily supplied by the relevant tradesmen groups in the market. Although these goods are placed on the market as health products, when using for pleasure purposes, they negatively affect human health. Therefore, the role of the state increased spontaneously in this process, since the issue is seen as a public health problem that concerns the society. This research, which aims to analyze the use of drugs in the Ottoman society and the state's strategy to struggle against it, aims to reveal the general situation of drug use affecting the Ottoman society and the perspective of the society and the state on drugs. Therefore, the problems in society and human health when the drug is used for pleasure purposes, and control policies of the state in areas such as legal, administrative, economic and health are tried to be considered within the framework of the holistic structure of the Ottoman state system.

Key Words: Drugs, addiction, opium, cannabis, Ottoman

\section{Giriş}

Uyuşturucu madde, insanın bedensel ve ruhsal yapısını etkilemesinin yanında toplumun ekonomik ve sosyal hayatında tesirler meydana getiren çok boyutlu bir kavram olarak ön plana çıkmaktadır. Uyuşturucu maddenin çok boyutu bünyesinde taşıması ise kavramın birçok bilim dalının ilgi alanına girmesine neden olmaktadır. Bu çerçevede fizyolojik yapıya etkileri 
bakımından sağlık bilimlerinin, insan psikolojisinde meydana getirdiği değişiklikler bakımından psikolojinin, toplumsal yaşama ve ilişkilere etkileri bakımından sosyolojinin, ekonomik hayata tesirleri bakımından iktisadın, dinen haram kabul edildiği için ilahiyatın, kanunlarca suç sayıldığı için de hukuk ve kriminoloji gibi çeşitli bilim dallarının ilgi alanına girmektedir.

Uyuşturucu madde, birçok alanı ilgilendiren bir hüviyete sahip olsa da her şeyden önce insan sağlığını ilgilendirdiği için uyuşturucu ve uyarıcı özelliği bulunan maddelerin değerlendirme sürecinde tıbbi bakış açısı daima önemli olmuştur. $\mathrm{Bu}$ noktada uyuşturucu madde, keyif amacıyla kullanıldığında bağımlılık durumu oluşturma, ruhi ve fiziki tahribata yol açma, merkezî sinir sistemini etkileme, kullanılan miktarı giderek arttırma ve nihayetinde ölümle sonuçlanma gibi menfi durumlara sebebiyet verdiği bilinmesine rağmen uyuşturucunun tedavideki rolü, uyuşturucu madde kaynaklarının tamamen yasaklanmasının önüne geçmiştir.

Tedavi edici ve ağn kesici özellikleri nedeniyle sağlık sektöründe vazgeçilmez ürünler arasında gösterilen uyuşturucu maddeler, kimyasal özellikleri bakımından doğal (tabii) maddeler ve sentetik maddeler olarak iki gruba ayrılmaktadır. Doğal maddeler, haşhaş ve kenevir gibi bitkilerden elde edilen maddeleri kapsamakta ve haşhaşın çizilmesiyle ortaya çıkan afyon, saf hâlde kullanılmasının yanı sıra morfin, kodein ve eroinin hammaddesi olarak; kenevir ise esrarın elde edildiği ana kaynak olarak işlev görmektedir. ${ }^{1}$ Uyuşturucu madde kaynakları içerisinde ikinci bir grubu ise laboratuvarlarda üretilen sentetik uyuşturucular meydana getirmekte ve amfetaminler ile yine kimyasal yollardan laboratuvarlarda üretilen "captagon" ve "ecstasy" en fazla bilinen sentetik uyuşturucular olarak dikkati çekmektedir. ${ }^{2}$

Eski medeniyetlerde olduğu gibi Türk-İslam medeniyetlerinde de uyuşturucu maddelerin asıl kaynağını doğal (tabii) maddeler içerisinde gösterilen haşhaş ve kenevir bitkisi teşkil etmiş ve bu durum, Osmanlı toplumuyla da devam etmiştir. Osmanlı toplumunda uyuşturucu maddelerin kaynağını oluşturan bitkiler içerisinde bilhassa haşhaş ve kenevir bitkisine öncelikli olarak tıp alanında müracaat edilmiştir. Bunlar içerisinde Osmanlı toplumunda "beng" adıyla zikredilen esrarın yanı sıra afyon ve karışımları, çeşitli ağrı ve sızının tedavisi ile öksürük gibi rahatsızlıklarda yumuşatıcı vazifesi gördüğünden tedavide yaygın şekilde kullanılmıştır. Diğer taraftan Osmanlı Klasik Dönemi'nden itibaren geleneksel usullerle imal edilen afyon, afyon macunları ve şurupları ile esrar türevi ürünler, zengin uyuşturucu içeriğine sahip oldukları için keyif verici bir madde olarak da talep görmüştür.

Osmanlı toplumunda uyuşturucunun keyif amacıyla kullanımı, toplumsal düzeni sağlamakla mükellef devlet otoritesinin sürece öncelikle hukuki ve idari açıdan dâhil olmasını getirmiştir. Bu noktada meselenin hukuksal bir kimliğe bürünmesi, adli ve idari birimlerin süreç içerisinde aktif şekilde yer almasını sağlamıştır. Ayrıca uyuşturucu kullanımının toplumsal ve ekonomik boyutları, devletin ilgili birimlerinin meseleye geniş bir perspektiften yaklaşmasını gerekli kılmıştır. Bundan dolayı Osmanlı Devleti’nde uyuşturucu madde meselesi, devlet tarafından mücadele edilmesi gereken çok boyutlu bir alan olarak değerlendirilmiştir.

\footnotetext{
${ }^{1}$ Özcan Köknel, Bă̆ımlılık (Alkol ve Madde Bă̆ımlılı̆̆l), Altın Kitaplar Yay. İstanbul 1983, s. 293; Mustafa Baktır, “Afyon”, İslam Ansiklopedisi, C. 1, TDV Yay., İstanbul 1988, s. 442; Esrar, kenevir (kendir) bitkisinden elde edilen uyuşturucu bir madde olup Türkiye'de esrar; İran'da beng / benc; Hindistan'da banga, ganja; Irak, Suriye ve Mısır'da haşiş; Kuzey Afrika'da kif; Amerika ve Meksika'da marijuana (marihuana) adlarıyla tanınmaktadır. Ayrıntılı bilgi için bkz. Turhan Baytop, "Esrar”, İslam Ansiklopedisi, C. 11, TDV Yay., İstanbul 1995, s. 431-432; Esrar, uyuşturucu kullanıcıları arasında en yaygını olup tıbbi açıdan afyona göre öldürücülüğü daha düşük olmasına rağmen fazla bağımlılık yapıcı ve öldürücü özelliği bulunan uyuşturuculara geçiş anlamında basamak olarak kullanılmasından dolayı dikkat edilmesi gereken bir maddedir. Alex Stevens, Drugs, Crime and Public Health (The Political Economy of Drug Policy), Taylor \& Francis Group, New York 2011, p. 25; Sulhi Dönmezer, Kriminoloji, Beta Yay., 8. Bask1, İstanbul 1994, s. 299-300.

2 Tuncay Başoğlu, "Uyuşturucu”, İslam Ansiklopedisi, C. 42, TDV Yay., İstanbul 2012, s. 248; Kültegin Ögel, Sigara, Alkol ve Madde Kullanım Bozuklukları: Tani, Tedavi ve Önleme, Yeniden Yay., İstanbul 2010, s. 3-4; Timur Demirbaş, Kriminoloji, 2. Baskı, Seçkin Yay., Ankara 2005, s. 273.
} 
Osmanlılarda keyif amacıyla uyuşturucu madde kullanımı ile devletin uyuşturucu madde kullanımına yönelik bakış açısını tahlil etmeyi amaçlayan bu araştırma, Osmanlı sosyoekonomik hayatında yansımaları görülen uyuşturucu madde kullanımına karşı toplumun ve devletin bakış açısı ile devletin mücadele stratejilerini ortaya koymayı hedeflemektedir. Bunun için de Osmanlı şair, düşünür ve ulemasının uyuşturucu maddenin keyif amacıyla kullanımına karşı yaklaşımları, kullanıcılara nasihatleri ile devletin adalet, idare, iktisat ve sağlık açılarından mücadele faaliyetleri, Osmanlı devlet sisteminin bütüncül yapısı çerçevesinde tahlil edilmeye çalışılmaktadır.

\section{Osmanlı Sosyoekonomik Hayatında Uyuşturucu Madde Kaynakları}

Osmanlı ekonomik ve toplumsal hayatı diğer Türk İslam medeniyetlerinin devamı niteliğindeki yapısıyla dikkati çekmiştir. Bu devamlılığın bir parçası olarak ekonomik, sosyal ve kültürel yapılarda geçmişten devralınan mirasın önemli izleri bulunmuştur. Osmanlı Devleti'nin geçmişten devraldığ 1 miraslardan birisi de tıbbi tedavi yöntemleri ve tedavide kullanılan bazı bitkilere yönelik tüketim alışkanlıklarıdır. Nitekim özellikle haşhaş ve kenevir bitkisi, Osmanlı sosyoekonomik hayatında uyuşturucu maddelere kaynaklık vazifesi görerek tedavide önemli bir yere sahip olmuştur.

Osmanlılarda sağlik alanında kullanılan maddelerden esrar; sıtma, romatizma, gut gibi hastalıkların tedavisinin yanı sıra çeşitli rahatsızlıklarda ağrı kesici işlevi görmüş, özellikle mide ve bağırsak ağrıları ile yarım baş ağrılarını gidermek için sıklıkla kullanılmıştı. ${ }^{3}$ Yine Osmanlı toplumunda "beng" adıyla zikredilen esrarın yanı sıra amber, tarçın, safran gibi aromatik maddelerle afyonun karıştırılması suretiyle de ağrı kesici ilaçlar elde edilmeye çalışılmıştır. Bundan dolayı afyon, Osmanlılarda en çok müracaat edilen ağrı kesici olarak kendini göstermiş, tedavide ise tentür veya ekstre hâlinde yaygın şekilde başvurulmuştur. ${ }^{4}$ Özellikle XIV. yüzyıldan itibaren yazılmış tıp eserlerinde tedavi edici özellikleri nedeniyle afyondan sıkça söz edilmektedir. Hatta bir tür afyonlu macun olan "berş" maddesinin sindirim sistemine (özellikle yemek hazım sorunu ve mide rahatsızlıklarına), boşaltım sistemine ve bel ağrılarına fayda sağladığı belirtilmekteydi. ${ }^{5}$ Nitekim afyon ve karışımları, toplumunun geneli tarafından benimsenerek anestetik amaçlarla çeşitli ağrı ve sızıların tedavisinde ve öksürük gibi rahatsızlıklarda yumuşatıcı vazifesi görmüş, sadece halk arasında değil, saray hekimlerince de yaygın şekilde kullanılmıştı. ${ }^{6}$

Osmanlı toplumunda afyon ve esrarın kaynağını oluşturan haşhaş ve kenevir bitkisi, sağlık alanındaki talebine paralel olarak zirai hayatta da ekonomik bir işleve sahip olmuştu. Bu doğrultuda bilhassa Batı Anadolu'da Afyonkarahisar şehri, afyon üretimiyle dikkati çekmişti. ${ }^{7}$ Yine Afyonkarahisar dışında Balıkesir, Kütahya, Uşak, İzmir, Manisa, Bolu, Bursa, Aydın, Konya, Tokat, Çanakkale, Tekirdağ, Edirne, Amasya, Tokat, Niğde, Malatya, Maraş ve Antep

\footnotetext{
${ }^{3}$ Ali Nahit Babaoğlu, Uyuşturucu ve Tarihi, Kaynak Yay., İstanbul 1997, s. 83; Turhan Baytop, "Esrar”, s. 431.

4 Afife Mat, "Osmanlı İmparatorluğu'nda Afyonun Tarihi”, Osmanlı Bilimi Araştırmaları, XI/ 1-2, 2009-2010, s. 285-286.

${ }^{5}$ Türk İslam hekimleri tarafından tedavi aşamalarında kullanılan afyon, Osmanlı hekimleri tarafindan da aynı şekilde kullanılmaya devam etmişti. Ahmed Ağırakça, "Osmanlı Tıbbının Kaynakları", Osmanlılarda Sağlık, C. I, Health in The Ottomans, ed. Coşkun Yılmaz-Necdet Yılmaz, Biofarma Yay., İstanbul 2006, s, 142-144; Sami Hamarneh, "Pharmacy in Medieval Islam and the History of Drug Addiction", Medical History, Volume: 16, Issue: 3, 1972. p. 230-231; Murat Uluskan, "İstanbul'da Bir Afyonlu Macun İşletmesi: Berş-i Rahîkî Macunhanesi (1783-1831)”, Türk Kültürü İncelemeleri Dergisi, S. 29, İstanbul 2013, s. 80.

${ }^{6}$ Miri Shefer Mossensohn, Ottoman Medicine: Healing and Medical Institutions, 1500-1700, NY Suny Press, New York Albany 2009, p. 39-40.

${ }^{7}$ Batı Anadolu'da eski adı Karahisar-1 Devle veya Karahisar-1 Sahib olan şehrin adı, XVI. yüzyıldan itibaren haşhaş üretiminin artmasına paralel olarak afyon üretim merkezi hâline gelmesi nedeniyle XVII. yüzyılda Afyonkarahisar adını almıştır. Üçler Bulduk, XVI. Asırda Karahisar-ı Sahib Sancağı, Yayımlanmamış DT, Ankara Ü. SBE, Ankara 1993, s. 272-274. XVII. yüzyılda bütün Anadolu'yu gezen Evliya Çelebi, Afyon şehrine de uğramış, eserinde geniş haşhaş tarlalarından bahsetmiştir. Evliya Çelebi, Seyahatnâme, IX. Kitap, hzl. Yücel Dağlı, Seyit Ali Kahraman ve Robert Dankoff, Yap1 Kredi Yay., İstanbul 2005, s. 21.
} 
şehirleri de afyon üretimi yapılan başlıca yerler olarak biliniyordu. ${ }^{8}$ Ayrıca içeriğinde bulunan afyondan dolayı uyuşturucu özelliği taşıyan macunlar da başta İstanbul'da olmak üzere Afyonkarahisar gibi afyon üretimi yapılan şehirlerde bir gelir kaynağıydı. ${ }^{9}$ Afyon, diğer taraftan da devlet için bir gelir kalemiydi ve "öşr-i afyon" adıyla toplanan vergi, XVI. yüzyıl içerisinde altı kat artarak hazineye önemli miktarda gelir sağlamıştı. ${ }^{10}$ Nitekim devletin afyonda elde ettiği öşür vergisi, sadece bu dönem için geçerli olmamış, daha sonraki dönemlerde de devletin vazgeçmediği vergi gelirleri arasında yer almıştı. ${ }^{11}$

Osmanlılarda afyon dışında kenevir bitkisi de geniş bir üretim alanına sahipti. Başta Karadeniz Bölgesi olmak üzere Anadolu'nun iç kesimlerinde ${ }^{12}$ ve Balkanlar'da ekilen zirai ürünler arasında kenevir bitkisi kendine rahatlıkla yer buluyordu. ${ }^{13} \mathrm{Bu}$ duruma örmek teşkil etmesi açısından XVI. yüzyılın ikinci yarısında Konya ve çevresinde toplam tarımsal üretim incelendiğinde, bunun \%1'inin kenevir ve keten üretiminden meydana geldiği görülmekteydi. ${ }^{14}$ Yine XVI. yüzyılda Karahisar-1 Sahib sancağının (Afyon) önemli gelir kaynakları arasında kenevir ve keten üretimi dikkat çekiyordu. ${ }^{15}$ Ayrıca İzmit, Bursa ve Musul şehri, üretim miktarı ve kalite açısından önde gelen yerler arasında sıralanıyordu. ${ }^{16}$

Osmanlı döneminde afyon ve esrarın çiftçiden alınıp yurt içine ve dışına satılması, belli bir sistem çerçevesinde gerçekleşiyordu. Kaynağını Osmanlı esnaflık teşkilatından alan bu sisteme göre bir malın mahallinde alınması, pazarlanması ve tüketiciye ulaştırılması yetkilendirilmiş esnaflar tarafindan yerine getiriliyordu. Süreçte herhangi bir aksaklık yaşanmaması için de devletin ve esnaf teşkilatının ilgili birimlerinin azami gayret göstermesi gerekiyordu. ${ }^{17} \mathrm{Bu}$ doğrultuda üretim bölgelerinden alınan özellikle afyon ve esrar gibi değerli ürünler, muhafazalı şekilde tüketim bölgelerine sevk ediliyor, oradan da piyasaya arz edilmek üzere yetkilendirilmiş esnaflara teslim ediliyordu. ${ }^{18}$ Örneğin İstanbul'da yetkili esnaf grubu olarak kabul edilen aktar esnafına bağlı faaliyetlerini sürdüren afyoncu ve benglikçi (esrarcı) esnafları, teslim aldıkları bu ürünleri günün koşullarına göre belirlenmiş bir fiyat üzerinden piyasaya arz ediyor, tüketiciler de yetkilendirilmiş bu esnaflara giderek ihtiyaçlarını temin ediyorlard1. $^{19}$

Osmanlı Klasik Dönemi'nde aktarlar esnafı tarafından satılan afyon ve esrarın sağlık ürünü olarak talep görmesi arzulanıyordu. Ancak Osmanlı toplumunda geleneksel usullerle

\footnotetext{
${ }^{8}$ Filiz Çolak, "Anadolu'da Afyon Ziraati ve Ticaretine Dair İzlenimler”, The Journal of Academic Social Science Studies, V. 6/1, January 2013, s. 516.

9 Suraiya Faroqhi, Osmanlı Kültürü ve Gündelik Yaşam (Ortaçağdan Yirminci Yüzyıla), Tarih Vakfi Yurt Yay., İstanbul 2005, s. 237-238.

${ }^{10}$ Nuran Taşligil ve Güven Şahin, "Tarihsel Süreçte Haşhaş ve Afyon”, Tarih Okulu Dergisi, S. XXXIV, Haziran 2018, s. 175; Ahmet Gümüşçü ve Osman Gümüşçü, "Türkiye'de Haşhaş ve Haşhaş Tarımının Coğrafi Dağılışı”, A.Ü. Türkiye Coğrafya Araştırma ve Uygulama Merkezi Dergisi, S. 6, Ankara 1997, s. 134.

11 “...1252 senesinden sonra afyonun sûret-i idâresi hakkında mukarrerât gereği 54 senesinden itibaren sekizde bir aynen öşr-i şer'î alınarak satışının serbest bırakılması..." Devlet Arşivleri Başkanlığı Osmanlı Arşivi (BOA), Maliyeden Müdevver Defter (MAD.d), nr. 9674, 11/03/1839 (25/Z/1254); BOA, MAD.d, nr. 8312, 29/12/1835 (9/N/1251).

12 Mehmet Taşdemir, "Karadeniz Bölgesinde Kendir-Keten Üretimi ve Kullanım Alanları”, Türk Kültürü Incelemeleri Dergisi, S. 8, İstanbul 2003, s. 1-24.

${ }^{13}$ Niş'in Leskofça kazasında bolca yetiştirilen kenevirden elde edilen dokuma numunelerinin Seraskerlik makamına takdimi hakkında bkz. BOA, Sadaret Mektubî Kalemi (A.MKT), nr. 28/57, 27/09/1845 (25/N/1261).

${ }^{14}$ Suraiya Faroqhi, Osmanlı'da Kentler ve Kentliler, Çev. Neyyir Kalaycığlu, Tarih Vakfi Yurt Yay., İstanbul 2000, s. 391-395.

${ }^{15}$ Bulduk, agt., s. 273-274.

${ }^{16}$ Esrarın etkili maddesi, kenevir bitkisinin çiçek durumları ve genç yapraklarında bulunan tüylerin taşıdığı reçinemsi madde içinde bulunmaktadır. Reçine miktarı Hindistan kökenli kenevirlerde \%10-20 arasındadır. Türkiye'de yetişen kenevirlerin de ortalama \%10 reçine taşıdıkları tespit edilmesine karşı Avrupa ülkelerinde bu oran ancak \%5 (bazen \%1-2) seviyesindedir. Turhan Baytop, “Esrar”, s. 432.

${ }^{17}$ Ahmet Kala, "Esnaf”, İslam Ansiklopedisi, C. 11, TDV Yay., İstanbul 1995, s. 425-426.

${ }^{18}$ Turhan Baytop, “Esrar”, s. 432;

${ }^{19}$ BOA, C.ML., nr. 450/18215, 29/04/1784 (08/C/1198).
} 
ekilen ve imal edilen afyon, afyon macunları ve şurupları ile esrar türevi ürünler, zengin uyuşturucu içeriğine sahip oldukları için tedavi amacı dışında keyif verici bir madde olarak da talep görüyordu. Devlet ise bu durum karşısında afyon, afyon macunu ve esrar türevi ürünlerin özellikle şifa maksadıyla üretilmesi ve kullanılması için mücadele ediyordu. ${ }^{20}$

Osmanlı toplumunda afyon başta olmak üzere esrar maddesinin sağlık alanında belirgin bir şekilde önem kazanması, XIX. yüzyılın başlarına tekabül etmektedir. Bu dönemde sanayileşme ve buna bağl1 gelişen ilaç sanayiindeki gelişmeler, morfin ve eroin ile esrar gibi maddelerin Avrupa'da tedavide uyuşturucu ve ağrı kesici olarak talep edilmesinin de önünü açmıştır. ${ }^{21}$ Nitekim ilk olarak XIX. yüzyılın başlarında 1804 yıllında morfinin bulunması, ${ }^{22}$ daha sonra 1832 yılında morfinden hareketle kodeinin izole edilmesine imkân sağlamıştır. ${ }^{23}$ Nihayetinde ilaç ve eczacılık alanında meydana gelen gelişmelerle birlikte XIX. yüzyılın ikinci yarısında afyonun kimyasal özelliklerinden hareketle morfinin sentezlenmesiyle birlikte yeni bir ürün olarak eroinde seri üretime geçilmesi, afyonun sınai bir ürün olarak değer kazanmasına katkıda bulunmuştu. ${ }^{24}$

Osmanlı Devleti de bu gelişmeye paralel olarak özellikle II. Abdülhamit devrinde bir tarım ve maliye politikası olarak afyon üretimini teşvik etmeye çalışmıştı. Teşvik kapsamında öne çıkan uygulamaların başında, çiftçilere bir yıldan üç yıla kadar vergi muafiyetleri ve kaliteli afyon üretimine yönelik çiftçilerin bilinçlendirilmesi geliyordu. ${ }^{25} \mathrm{Bu}$ süreçte teşviklerin de etkisiyle üretim artışından dolayı Avrupa'da sağlık sektöründe aranan bir ürün hâline gelen Osmanlı afyonu, XIX. yüzyılın ikinci yarısından itibaren en fazla ihraç edilen tarım ürünleri arasına girmeyi başarmıştı. ${ }^{26}$ Ağırlıklı olarak Osmanlı topraklarında üretilen afyonun ilaç firmalarına ait laboratuvarlarda morfinin asetik asit, yani sirke asidi etkileşimiyle geliştirilen eroin ise ilaç piyasasında önemli bir pazar elde etmeye başlamış, kısa süre içerisinde İngiltere başta olmak üzere Avrupa'nın diğer ülkelerinde ve dünya genelinde yaygınlık kazanmıştı.

${ }^{20}$ Evliyâ Çelebi Seyahatnâmesi II. Kitap, hzl. Seyit Ali Kahraman ve Yücel Dağlı, Yapı Kredi Yay., 5. Bask1, İstanbul 2008, s. 607-608; Amasyan Efendi, Afyon Tohumu Ziraatı Layihası, La Türki Matbaası, İstanbul 1287, s. 3; Ali Haydar, Haşhaş Ziraatı, Matbaa-i Osmaniyye, Dersaadet 1330, s. 5, Turhan Baytop, "Eczacılık", İslam Ansiklopedisi, C. 10, TDV Yay., İstanbul 1994, s. 387.

${ }^{21}$ Avrupa'da XIX. yüzyılda afyon, yaygın bir sakinleştirici ve ağrı kesici olarak kullanılmış, eczanelerde reçetesiz olarak satılan ve aile hekiminin de en çok yazdığı ilaç hâline gelmiştir. Günümüzdeki Aspirin’e benzer bir rol oynayan afyon, isterik ve sinirli kişileri yatıştırmada, yolculuk öncesi heyecana, migrene vs. karşı da kullanılmaktaydı. Ayrıntılı bilgi için bkz. Wolfgang Schivelbusch, Keyif Verici Maddelerin Tarihi, çev. Zehra Aksu Y1lmazer, Genesis Kitap Yay., Ankara 2012, s. 211.

${ }^{22}$ Martin Booth, Haşhaştan Eroine Uyuşturucunun 6000 Yıllık Öyküsü, Sabah Kitapları, İstanbul 1996, s. 60.

${ }^{23}$ Köknel, age., 1983, s. 293; Taşlıgil ve Şahin, agm., s. 176.

${ }^{24}$ XIX. yüzyılda elde edilen uyuşturucu maddeler içerisinde en önemlilerinden birisi de eroindir. Yarı sentetik bir madde olarak eroin ilk olarak 1874 yılında Londra'da "St Mary's Hospital"da morfinin kimyasal özelliklerinin dönüştürülmesiyle elde edilmiş ve daha sonra da Almanya başta olmak üzere diğer Batılı ülkelere yayılmıştı. Ayrıntılı bilgi için bkz. Louise Foxcroft, The Making of Addiction (The 'Use and Abuse' of Opium in NineteenthCentury Britain), Published by Ashgate, England 2007, p. 10; F. Cengiz Erdinç, Overdose Türkiye, İletişim Yay., İstanbul 2004, s. 24-25.

${ }^{25}$ Donald Quataert, Anadolu'da Osmanlı Reformu ve Tarımı (1876-1908), çev. Nilay Özok Gündoğan ve Azat Zana Gündoğan, Türkiye İş Bankası Kültür Yay., 2008, s. 244. Afyon üreticilerine sağlanan teşvik ve kolaylıklar içerisinde çoğunlukla birer yıllık öşür vergisi muafiyeti uygulanıyordu, bkz. Devlet Arşivleri Başkanlığı Osmanlı Arşivleri (BOA), Dâhilî Mektûbat (DH.MKT), Dosya No: 2370 ve Gömlek No: 7 (nr. 2370/7), Tarih: 10/03/1901 (19/ZA/1318). Hasıl olan afyon ve haşhaş tohumlarından devletin sekizde bir oranında öşür vergisi aldığı görülmekteydi. BOA, Hazine-i Hâssa Nezareti Defterleri (HH.d), nr. 24838, 08/01/1841(07/ZA/1256).

26 Örneğin 1897 yılına gelindiğinde Osmanlı tarım ürünleri ihraçları arasında üzüm, incir, zeytinyağından sonra dördüncü sırada 62 milyon kuruşluk değeriyle afyon yer alıyordu. Diğer taraftan toplam mal ve ürün ihracatında ise afyon, altınc1 sirada kendine yer buluyordu. Donald Quataert, “The Ages of Reforms 1812-1914”, An Economic and Social History of the Ottoman Empire 1300-1914, ed. Halil İnalc1k ve Donald Quataert, Cambridge Univ. Press, 1996, s. 833. 
Ancak eroinin çeşitli faydalarına rağmen insan sağlı̆̆ı üzerinde özellikle bağımlılık yapıcı etkileri, dünyayı etkilediği gibi Osmanlı toplum sağlığını da beraberinde etkilemiştir. ${ }^{27}$

\section{Osmanlı Toplumunda Uyuşsturucu Madde Kullanımı}

Afyon ve esrar, sağlık alanındaki kullanımının yanı sıra İlk Çağ toplumlarından itibaren keyif amacıyla kullanılan ürünler olarak dikkati çekmiştir. İslam toplumlarında ise IX. yüzyıldan itibaren ortaya çıkan keyif amacıyla kullanım, daha sonra Türk İslam toplumlarına sirayet etmeye başlamış ve Osmanlı toplumuyla devam etmiştir. ${ }^{28}$

Osmanlı toplumunda tıbbi gerekçeler dışında keyif amacıyla kullanılan uyuşturucu maddelerin kaynağını oluşturan afyon ve esrar, toplumun geneline yansımasa da arz imkânlarındaki kolaylıkların da etkisiyle rahatlıkla temin edilebilmekteydi. Dolayısıyla Osmanlı Klasik Dönemi'nden başlamak suretiyle Osmanlı Devleti'nin son anlarına kadar afyon, afyon macunları ve şurupları ile esrar türevi ürünlerin neşelenmek ve bazı sorunlardan uzaklaşmak amacıyla belli bir kullanım alanına sahip olduğu görülmekteydi.

\subsection{Osmanlı Klasik Dönemi’nde Uyuşturucu Madde Kullanımı}

Osmanlılar Döneminde tütün dışında keyif amacıyla kullanılan maddelerin başında afyon ve esrar gelmiş, bu maddelerin müptelasına da "tiryaki" adı verilmiştir. Keyif verici bu maddelere alışanlar da kullandığı maddenin cinsine göre toplumda "afyon tiryakisi" ve "esrar tiryakisi” olarak isimlendirilmiştir. ${ }^{29}$

Osmanlı Klasik Dönemi'nde tiryakiler, belli yerlerde toplanırlar ve bunların başında ise İstanbul Süleymaniye'deki "Tiryakiler Çarşısı" dikkati çekerdi. ${ }^{30}$ Tiryakiler Çarşısı'nda uyuşturucu madde kullananların büyük kısmını ise afyon tiryakileri oluşturur ve bunların pek çoğunun da Süleymaniye Camii karşısında ve medreselerin altında otuz beş dükkândan ibaret sıra kahvelere devam ettiği bilinirdi. Ayrıca tiryakilerin kendi semtlerinde de devam ettikleri pek çok kahvehane vardı. Fakat Süleymaniye'deki Tiryaki Çarşısı, genellikle gecenin ilerleyen saatlerine kadar açık olur ve tiryakiler için bir nevi gizli bir toplanma mekânı hâline gelirdi. ${ }^{31}$

Osmanlı Döneminde İstanbul'da afyon içicilerin toplandığı kahvehanelerde özel olarak hazırlanmış afyon, çubuk veya kabak denilen aletlerde yakılır ve meydana çıkan dumanı çekilirdi. ${ }^{32}$ Ayrıca afyon tiryakileri afyona mercimekten daha küçük bir miktarla başlar, yavaş yavaş iri fındık büyüklüğüne kadar yükseltirlerdi. Hatta zamanla birkaç misline çıkaran, bu afyonla bile keyiflenemediği için içine "ak sülümen" adı verilen zehri katan tiryakiler dahi bulunurdu. ${ }^{33}$ Nitekim XVI. yüzyılın düşünürü Gelibolulu Mustafa Âli de afyon tiryakilerini şu şekilde tasvir etmektedir: ${ }^{34}$

\footnotetext{
${ }^{27}$ Schivelbusch, age., s. 215, 219; Babaoğlu, age., s. 54-55; Toby Seddon, “The Regulation of Heroin: Drug Policy and Social Change in Early Twentieth-Century Britain”, International Journal of the Sociology of Law, Volume 35, Issue 3, September 2007, p. 143-144; Taşligil ve Şahin, agm., s. 168,176.

${ }_{28}$ Rüya Kılıç, “'Afyonun Keyfini Tiryakisinden Sormalı’: Osmanlı ve Erken Cumhuriyet’te Madde Bağımlılığ Tarihi”, Kebikeç, S. 42, 2016, s. 148; Hamarneh, agm., p. 230-231.

${ }^{29}$ Osmanlıcada keyif vericilere alışanlara "afyon tiryakisi”, "enfiye tiryakisi”, "tütün tiryakisi” denilirken söz konusu keyif vericilerden birine müptela olanlar kastedilirdi. Ayrıntılı bilgi için bkz. Abdülaziz Bey, Osmanlı Âdet, Merasim ve Tabirleri, hzl. Kâzım Arısan, Duygu Arısan Günay, Tarih Vakfı Yurt Yay., İstanbul 1995, s. 325; Başoğlu, agm., s. 249; Kılıç, agm., s. 151.

${ }^{30}$ Evliyâ Çelebi Seyahatnâmesi (I. Kitap), hzl. Orhan Şaik Gökyay, Yap1 Kredi Yay., İstanbul 1999, s. 288; Turhan Baytop, agm., s. 431-432.

${ }^{31}$ Abdülaziz Bey, age., s. 325-327.

${ }^{32}$ Afife Mat, agm., s. 286.

33 Osmanlılarda afyon tiryakileri, afyon ile kahveyi birlikte tercih etmekten hoşlanırlardı. Tiryakiler, kahvenin yanında afyonu yutar, keyfini yeniler, sonra güçlükle yoluna devam ederdi. Abdülaziz Bey, age., s. 326.

${ }^{34}$ Gelibolulu Mustafa Âli, Mevâidü'n-Nefâis Fî Kavâidi'l Mecâlis I (Görgü ve Toplum Kuralları Üzerinde Ziyâfet Sofraları), hzl. Orhan Şaik Gökyay, İstanbul 1978, s. 88.
} 
"Tiryakiler, gerçi Tanrı buyruğundan çıkıp azmış olanların gözüne aşağılık görünürler, ama afyon yutup keyifleri, neşeleri gelince hünkâr olurlar. Geçkin iken her sözleri öldürücü ağunun ta kendisidir."

Başkent İstanbul'da tiryakilerin birçoğu vaktiyle esnaflık yapmış, ihtiyarlayınca işten çekilmiş kimselerdi. Bir kısmı da vezirlerin ve valilerin maiyetinde taşralarda gezmiş, iç ağalık veya kavaslık hizmeti görmüş, yaşlandıktan sonra evlerinde oturan kimselerdi. Bunlar eline her geçeni buralarda harcayarak afyona müptela olmuşlard $1{ }^{35}$ Tiryakiler, afyonun tesiriyle çok zayıf düşmüş, çelimsiz ve çoğu da yaşlı olan kimselerdi. Saldırgan eğilimlerde genellikle bulunmayan bu kişiler, sokaklarda bilinçsizce dolaşırlardı. ${ }^{36}$

Afyon tiryakilerinin sağlıklarını önemsemeyerek sürdürdükleri sefil yaşantı, İstanbul dışındaki yerlerde de karşılaşılan hadiseler arasındaydı. Bunlar içerisinde özellikle haşhaştan afyon elde edildiği için adını buradan alan Afyonkarahisar şehri için de aynı durum geçerliydi. Nitekim Evliya Çelebi burada afyon kullanımının yaygın olduğuna ve sadece kullanımın erkeklerle sınırlı kalmadığını, kadınların da kullanımına rastlandığına ve şehir halkının benizlerinin soluk ve sararmış, fiziksel görünümlerinin de zayıflamış hâlde olduğuna dikkat çekmekteydi. ${ }^{37}$

Osmanlı toplumunda afyondan elde edilen diğer önemli bir keyif verici maddeye ise "berş" adı veriliyordu. Afyon şurubu ve keten yaprağı karışımından yapılan berş, bir nevi macun olarak bilinmekteydi. ${ }^{38}$ Afyon karışımından elde edilen berş (macun) kullanımına, XVI. yüzyılda belli sınırlar çerçevesinde hoşgörüyle yaklaşılmasından dolayı özellikle başkent İstanbul'da berş kullanımının yaygın olduğu görülmekteydi. ${ }^{39}$ Bunlar içerisinde "Berş-i Râhîkî" adıyla anılan ve afyon ile şarap türevlerinin karışımları sonucu elde edilen Rahîkî macunu, XVI. yüzyıldan itibaren şifa ve ilaç maksadıyla üretilmiş olsa da keyif amacıyla da kullanılan bir macun olarak biliniyordu. ${ }^{40}$

Osmanlı toplumunda keyif amacı taşıyan uyuşturucu maddeler içerisinde yer alan berş, çeşitli şekillerde kullanılıyordu. Özellikle eskiden tiryaki kahvelerinde kahveden evvel bir fincan berş şurubundan vermenin âdet olduğu, berş macununun uyuşturucu madde kabilinde yer aldığı ve Osmanlılarda afyon ve esrara oranla daha fazla kullanıldığı biliniyor ve bunu kullananlara da "berrâş" deniliyordu. Ayrıca bu maddenin insan sağlığı ve sosyal ilişkilerde yıkıma sebebiyet verdiği divan şiirlerine dahi konu oluyordu. ${ }^{41}$

Osmanlı Klasik Dönemi'nde keyif amacıyla kullanılan önemli maddelerden birisi de kenevirden elde edilen esrardı. Kurutulmuş nebati bir madde olan esrar, Osmanlı'da "beng"

\footnotetext{
${ }^{35}$ Abdülaziz Bey, age., s. 326 .

${ }^{36}$ Reşad Ekrem Koçu, "Afiyoncular, Afiyon Tiryakiliği Yasă̆ı", İstanbul Ansiklopedisi, C. 1, İstanbul 1958, s. 228.

37 "Ammâ halkının reng-i rûyları saruya mâyillerdir, zîrâ bu diyâr afyon kânı olmağile halkının ekseri tiryâkîlerdir. Ammâ âb (u) hevâsının letâfetinden halkı tiryâkîliklerine göre nâne çöpü gibi ve yâdes kemiği-misâl arı âdemlerdir... Tiryâkî olduklarından dâ'imâ vâkl'a gördükleri hâlleri cümle vâki'dir... Avret ola ve tiryâkî ola, ne’ûzü billâh. Anıniçün ehilleri hânelerine gelmeyüp kahvehânelerde kıssahân ve gazelhân dinleyerek hânelerine gitmeğe iktidârları olmayup kaşına kaşına kahvede uyuya kalır, zîrâ evine varsa avreti tiryâkî kendüsi dahi tiryâkî iki lecûc bir yerde hüsn-i zindegâne edemediklerinden ekseriyyâ ehl-i hirefleri kahvede mihmân olur...” bkz. Evliyâ Çelebi Seyahatnâmesi (IX. Kitap), hzl. Yücel Dağlı, Seyit Ali Kahraman ve Robert Dankoff, Yapı Kredi Yay., İstanbul 2005, s. 21.

${ }^{38}$ Gelibolulu Mustafa Âli, age., s. 326.

${ }^{39}$ Metin Öztürk, Sihhatî Çelebi'nin "Menâkıb-ı Mükeyyifât-ı Âlem” Risalesi Çerçevesinde 17. Yüzyıl İstanbul'unda Keyif Verici Maddeler, Yayımlanmamış YLT, Hacettepe Ü. SBE, Ankara 2006, s. 32; Suraiya Faroqhi, Osmanlı Kültürü ve Gündelik Yaşam (Ortaçă̆dan Yirminci Yüzyıla), Tarih Vakfi Yurt Yay., İstanbul 2005, s. 237.

${ }^{40}$ Uluskan, agm., s. 81-82.

41 "Hûşyârı tükendi ikiden hâli değildir / Şimdi bu cihân halkı ya ayyâş u ya berrâşs" Erzurumlu Zihnî, G 68/4, bkz. Abdulkadir Erkal, "Divan Şiirinde Afyon ve Esrar”, Atatürk Ü. Türkiyat Araştırmaları Enstitüsü Dergisi, S. 33 Erzurum 2007, s. 47. "Berş, görünüşte içinde bengi suyun bulunduğu karanlıkları andırır. Çünkü karadır, ama berş bulamayınca tiryakiler, çaresizce kahveye yönelirler.” Gelibolulu Mustafa Âli, age., s. 88.
} 
adıyla zikredilmekte ${ }^{42}$ ve Osmanlı Klasik Dönemi'nden itibaren "beng" imali ile satışılyla ilgili İstanbul'da "esnâf-1 bengciyân" adı verilen bir esnaf zümresi dahi bulunmaktaydı. Süleymaniye semtindeki Tiryakiler Çarşısı'nda yer alan bu esnaflar, dükkânlarında şurup, macun, levha gibi esrar ihtiva eden müstahzarlar hazırlayarak tiryakilerin kullanımına sunmaya çalışıyorlardı. Nitekim Evliya Çelebi bu esnaf grubunun esrar satıcısı olmasının yanında aynı zamanda kullanıcısı olduğunu ve şevk ehli bu esnafların esrar yiyerek, gülerek, şakalar ederek "bengileriz, karnımız aç" diyerek birbirleriyle eğlendiklerini ifade etmektedir. ${ }^{43}$

Başkent İstanbul'da esrar kullanıcıları sadece Tiryakiler Çarşısı ve civarında yer almıyorlardı. "Tavukpazarı"nda, "İskilip Hanı" civarında, "Vezir Hanı" içinde, "Binbirdirek" semtinde, Aksaray'ın tenha yerlerinde, pek çoğu da "Tahtakale" civarında esrar kullanıyorlardı. Buralarda madde kullanan kişiler, herkese açık ortamlarda sokak ve caddelerde değil, daha çok kendi aralarında bildikleri kapalı sayılabilecek mekânları tercih ediyorlardı. ${ }^{44}$

Esrar ve diğer bağımlılık yapıcı maddelere bağımlı olan kişilerin içine düştükleri kötü hâller ve topluma karşı oluşturdukları riskler, toplumsal sorunlara ilgi duyan Osmanlı düşünürlerinin de dikkatini çekmiştir. Bunlar içerisinde Gelibolulu Mustafa Âli Efendi, esrar tiryakilerinin sarhoş oluncaya kadar esrar çektiklerinde iğrenç olduklarını vurgulamıştır. ${ }^{45} \mathrm{Bu}$ alanda önemli çalışmalarda bulunmuş Sıhhatî Çelebi de risalesinde esrar bağımlılarının ağzından çıkan sözü kulağının duymadığını, esrarın etkisiyle akıl melekesinin ortadan kaybolduğunu kendine has üslubuyla tasvir etmektedir. ${ }^{46}$ Yine XVII. yüzyılın büyük ilim adamlarından Kâtip Çelebi de esrar başta olmak üzere diğer keyif verici madde kullananlara şu şekilde nasihat ve tavsiyelerde bulunmuştur: ${ }^{47}$

“... Nerde kaldı ki gerektirir bir hâl yok iken salt keyfi vardır diye bu türlü nesnelere alışıp birkaç kez almakla vücudun ihtiyacı hâline gelsin, sonradan vazgeçmek mümkün olmaz. Ömrün sonuna dek acısı çekilip yaş ilerledikçe bel bükülüp kılık kıyafet kilise duvarında yer yer bozulan surete döner. Keyf gelir, bir anda geçer; insanın gücü ve takati kesilip vukuf ve şuur gider, ne ölü ne diri ne uyumuş ne uyanık, sallanıp kalır. Beğenerek ve isteyerek bu kerteye varanların kendilerine büyük gadrettiklerine şüphe mi var? Bundan sonra eğer müyesser olup bir yolla kesebilirse büyük bir firsat ve ganimettir, kaybetmemek gerekir. Eğer müyesser olmazsa birden kesmek tehlikelidir, çaresiz kullanır ve şeriatça da birakılmasına izin yoktur. Ve bir kez tutulup tiryakisi olduktan sonra keyf erbabına karışmak ve sataşmak ahmaklıktır ve hatadır. Nihayet sözümüz henüz tiryakilik tuzağına düşmeyenleri gafletten uyarmak için..."

Osmanlı toplumsal hayatında afyon ve esrar tiryakiliği üzerine dikkat çeken önemli bir isim de XVII. yüzyılın ikinci yarısı ile XVIII. yüzyıl başlarının önemli şair ve düşünürlerinden olan Nâbi'dir. "Hayriyye" adli eserinde Nâbi, afyon ve esrar tiryakiliğinin kötü huylardan olduğunu vurgulayarak tiryakileri şöyle tasvir etmektedir: ${ }^{48}$

\footnotetext{
42 "Beng”, birçok kaynakta afyon gibi uyuşturucu ve keyif verici "ban” denilen yapraklı bir nebat ve bunun tohumu olarak zikredilmektedir. Ayrıntılı bilgi için bkz. Ferit Develioğlu, Osmanlıca Türkçe Ansiklopedik Lûgat, Aydın Kitabevi, 30. Bask1, Ankara 2013, s. 107; Gelibolulu Mustafa Âli, age., s. 326. Bununla birlikte sadece ban otunu ifade etmediği, belli çevrelerde veya bazı dönemlerde bununla Hint keneviri ve diğer bitkilerden çıarılan uyuşturucuların da kastedildiği anlaşılmaktadır. Nitekim Fuzûlı̂’nin Beng ü Bâde adlı eserinde beng "esrar" anlamında kullanılmakta ve Osmanlı kaynaklarında bu kavram daha çok esrarı ifade etmektedir. Başoğlu, agm., s. 249.

${ }^{43}$ Evliyâ Çelebi Seyahatnâmesi (I. Kitap), age., s. 288; Turhan Baytop, agm., s. 431-432.

${ }^{44}$ Abdülaziz Bey, age., s. 327-328.

45 “...Cevcevinde pâklerdir şöyle kim ve müstekreh ü murdar olur tiryakiler” bkz. Gelibolulu Mustafa Âli, age., s. 88.

46 “... her kim ki seni isti'mâl ider ise 'akl dâiresinden berî ve fehm neş'esinden mahrûm olur ve dâ 'imâ bilâ-sebeb yok yere gülüp mudhaku'l-âlem olup ağzından çıkan kelâmı kulağı işitmez...” bkz. Metin Öztürk, agt., s. 35.

${ }^{47}$ Kâtip Çelebi, Mîzan'ül-Hakk Fi İhtiyari'l-Ahakk, hzl. Orhan Şaik Gökyay, Tercüman 1001 Temel Eser, İstanbul 1980 , s. 50-51.

${ }^{48}$ Nâbi tarafindan 1701 yılında yazılan adı Hayrînâme olduğu hâlde daha çok Hayriyye diye tanınan eserde afyon ve esrarın zararları 684. ve 685. sayfalarda edebî bir dille anlatılmaktadır. Ayrıntılı bilgi için bkz. Nâbi, Hayriyye, hzl. Mahmut Kaplan, Kültür ve Turizm Bakanlığı Yay., Ankara 2019, s. 104.
} 
"Ârız-ı keyfe sakın olma zebûn

Olma âlûde-i berş ü afyûn

\section{Beng ü esrâr dahi bed-terdür}

Yiyen insan degül anı hardur",

Osmanlı toplumsal ve ahlaki hayatına 1şık tutması açısından nasihatnâme tarzında eserler ortaya koyan ve XVIII. yüzyılın ikinci yarısındaki sosyal hayata 1şık tutan isimlerden birisi de Sünbülzâde Vehbî'dir. Lutfiyye adlı eserinde özellikle gençlerin keyif veren maddeler olarak ifade edilen içeceklerden afyon, beng ve berş maddelerinden uzak durmasını nasihat etmektedir. Vehbî, bu yaklaşımıyla afyon ve afyon şurubuna müptela olmanın sonuçlarına edebî bir dille şu şekilde dikkat çekmektedir: ${ }^{49}$

\section{"Ne belâdur hele berş ü efyûn}

Ki eder âdemi süst ü mecnûn”

Yine Sünbülzâde Vehbî, esrar kullanımının ciddi anlamda bilinç ve davranış problemlerine sebep olduğunu ise şöyle ifade etmektedir:

\section{"Bengî ketm eyleyemez esrârın \\ Şîre-keş tatlu sanur güftârın"}

Osmanlı Klasik Dönemi olarak kabul edilen ve geleneksel yapının henüz ciddi anlamda değişime uğramadığı bu dönemde şair, düşünür ve devlet adamları tarafindan karşılık bulan nasihatnâme türündeki yaklaşımlar, bu dönemdeki Osmanlı toplumsal yaşamını yansıtması açısından önemlidir. Nitekim afyon ve esrarın keyif amacıyla kullanıldığında birçok fiziksel ve ahlaki problemlere yol açtığına dair dikkat çeken değerlendirmeler ve devletin resmî görüşleri, XIX. yüzyılda da aynı şekilde önemini korumuştur.

\subsection{Osmanlı Yenileşme Dönemi'nde Uyuşturucu Madde Kullanımı}

Osmanlı Devleti'nde XIX. yüzyıl, Avrupa ile ekonomik ve sosyal ilişkilerin geliştiği, Batı ile etkileşimin giderek arttığı bir dönemi içine almaktadır. Yenileşme Dönemi olarak bilinen Cumhuriyet'e kadar devam eden bu zaman diliminin Osmanlı açısından belirgin özelliği; ekonomik, sosyal, siyasi ve hukuki alanda Avrupa ile temasın giderek artış göstermesidir. Nitekim artan temasın göstergesi olarak bu dönemde bir taraftan Osmanlı tebaası Avrupa'yı yakından tanımaya başlarken diğer taraftan da Avrupalılar, Osmanlı coğrafyasına yaptıkları ziyaretlerle sosyal ve ekonomik yaşamı yakından tanıma firsatına sahip olmuşlardır.

XIX. yüzyıldan itibaren Osmanlılarla Avrupalıların temasları sonrasında Avrupalıların Osmanlı toplumuna ilişkin gözlemleri dikkat çekici olup yabancıların gözlemlerinde ilgisini çeken meselelerden birisi de Osmanlı Klasik Dönemi'nde de görülen uyuşturucu madde alışkanlığıdır. Nitekim yabancılardan Dr. Mongeri, 1860'lı yıllarda İstanbul'da görülen akıl hastalıklarının bir sebebinin de uyuşturucu madde kullanımı olduğunu belirtikten sonra İstanbul'a gelen esrarın yarıdan fazlasının Osmanlı toprakları olan Suriye ve Misır tarafina gittiğini belirtmektedir. ${ }^{50}$ Ayrıca bu döneme ilişkin Zambako Paşa da 1882 yılında bir Tıp Kongresi'nde sunduğu bildiride, Osmanlı toplumunda bazı kısıtlamalara rağmen uyuşturucu maddeler içerisinde afyon kullanımına bu dönemde belli ölçülerde rastlandığını, kullanım

\footnotetext{
${ }^{49}$ Mahmut Gider, "Keyif Verici Maddelerden Uzak Durmanın Gerekliliği: Sünbülzâde Vehbî’nin Lutfiyye Mesnevisi Örneği”, Osmanlı Mirası Araştırmaları Dergisi, C. 6, S. 14, Mart 2019, s. 31-32. Çağının toplumsal sorunlarını, hamasi ve mistik duygularla değil, sağduyu sahibi bir aydın akılcılığıyla devletin ve toplumun o devirdeki durumunu gözler önüne sermeyi bașaran Sünbülzâde Vehbî’nin nasihatnâme türündeki Lutfiyye adlı mesnevisi hakkında bkz. A. Azmi Bilgin, "Lutfiyye”, İslam Ansiklopedisi, C. 27, TDV Yay., Ankara 2003, s. 236-237; Süreyya Ali Beyzâdeoğlu, Sünbülzâde Vehbî Lutfiyye, Cihan Neşriyat ve Matbaacılık, İstanbul 1996.

${ }^{50}$ Turhan Baytop, "Esrar”, s. 432.
} 
biçiminin ise genel olarak hap şeklinde ve miktar açısından da günde 1-3 gr. arasında değiştiğini belirtmiştir. ${ }^{51}$

Osmanlı toplumunda uyuşturucu maddenin keyif amacıyla kullanımının açtığı sorunlar, XIX. yüzyıl ile XX. yüzyılın başlarında yaşamış bazı yazarların da ilgisini çekmiştir. Bunlar içerisinde alanında önemli bir eser vermiş Abdülaziz Bey, İstanbul'da afyon ve esrar tiryakilerinin bulunduğuna dikkat çekerek, tiryakilerin içine düştükleri hâlleri eserinde ayrıntılı şekilde anlatmaktadır. ${ }^{52}$ Yine bu dönemde yaşamış Muallim Şövalye Hasan Bahri de özellikle esrarkeşlerin durumlarının nasıl ilerlediğini altı aşamalı olarak kendine has bir üslupla tasvir ederek, bağımlıların içine düştüğü ekonomik, sosyal ve sağlık sorunlarının kendilerini nasıl bir girdaba sürüklediğini ayrıntılı şekilde gözler önüne sermektedir. ${ }^{53}$

XIX. yüzyıl ile XX. yüzyılın başlarında yaşamış bu yazarların anlatımlarına göre Osmanlılarda özellikle esrar kullanıcılarına olumlu gözle bakılmıyor, esrarkeşlerin söz ve davranışlarının toplumda fazla bir karşılığı bulunmuyordu. Çünkü esrarkeşlerde madde kullanımıyla birlikte görülen tutum ve davranışlar diğer keyif vericilerinkine benzemiyor, normal bir insandan hiç beklenmeyecek hareketlerde bulunuyorlard ${ }^{54}$ Nitekim esrar vehim ve hayallere sebep olduğundan esrarkeş su görse deniz sanır, derhâl soyunmaya kalkışır, yüzmek ister, önüne bir değnek konsa suskun ve şaşkın bir hâlde bakar, bir hayli düşünür, üstünden atlayıp geçemezdi. Ayrıca esrarkeşler, gereksiz yerde yüksek sesle kahkahalarla gülmeye başlar, sanki birisiyle konuşuyormuş gibi kendi kendine bir sürü anlamsız sözler söyler, arada bir sebepsiz hiddet firtınalarına kapılır ve gülünç hâllere düşerlerdi. ${ }^{55}$

Tanzimat'tan Cumhuriyet'e devam eden Yenileşme Dönemi'nde esrar tiryakilerinin ekonomik ve sosyal durumları ise Abdülaziz Bey tarafindan şöyle tasvir edilmektedir: Esrarkeşler genellikle işsiz, güçsüz ve harabatiliğe düşmüş kimselerdir ve afyon tiryakilerinde olduğu gibi esrarkeşler içerisinde efendiden, ağadan pek kimse bulunmaz. Bunlar İstanbul'un çok eski âdetine göre çoğunlukla kibar konaklarına seyis ve tablakâr alarak gelmiş, ihtiyarlayınca ya da boşluğa düşünce sarhoşluğu esrarkeşliğe döndürmüş kişilerdir. Ayrıca esrarkeşler, eskiden beri serseri güruhundan oldukları için devam ettikleri esrarhanelere borçları bulunur, bunu ödeyemeyince hırsızlık yapar, başka yerde çaldıklarını satarak borçlarını ödemek zorunda kaldıkları için de esrarkeşler hem kendilerine hem de başkalarına zarar verir. ${ }^{56}$

XIX. yüzy1ldan itibaren afyon ve esrar tiryakilerinin içine düştüğü fiziksel, ekonomik, sosyal ve psikolojik hâller, toplumun uyuşturucu maddeye karşı bilinçlenmesi adına önemli gelişmeler olarak kabul edilse de bu dönemde Osmanlı toplumunu etkilemesi bakımından dünyada etkileri olan Batı kaynaklı iki önemli gelişme meydana gelmiştir. Birincisi, uyuşturucu maddelerin uluslararası ticaret metaı hâline gelmesiyle büyük kazançlar elde edilmesi ve devamında meşhur afyon savaşlarına doğru giden sürecin başlaması, ikincisi de kimya sanayiinin gelişimiyle eskisine göre daha zararlı ve daha fazla bağımlılık yapıcı sentetik

\footnotetext{
${ }^{51}$ Turhan Baytop, Türkiye'nin Tıbbi ve Zehirli Bitkileri, İstanbul Ü. Yay., İstanbul 1963, s. 246.

52 1850-1918 Yılları arasında yaşamış Abdülaziz Bey, Osmanlı Âdet, Merasim ve Tabirleri adlı eserinde İstanbul'da yaşayan afyon ve esrar tiryakilerinin toplanma yerleri, madde kullananların bilinçsiz hâl ve hareketleri hakkında ayrıntılı bilgiler sunmaktadır. Ayrıntılı bilgi için bkz. Abdülaziz Bey, age., s. 325-329.

${ }^{53}$ Hasan Bahri'ye göre esrarkeşlerin yaşamları altı basamaktan meydana gelmekte olup bu basamaklar şu şekildedir: 1. Basamak: Neş’e, 2. Basamak: Za'fiyet, 3. Basamak: Kayıtsızlık, 4. Basamak: Sefâlet, 5. Basamak: Hastane ve 6. Basamak: Mezar. Ayrıntılı bilgi için bkz. Muallim Şövalye Hasan Bahri, Esrarkeşler, hzl. Süha Ünsal, Kebikeç Yay., Ankara 1997, s. 25.

${ }^{54}$ XIX. yüzyılda yaşamış ve bu alanda eserler vermiş Hasan Bahri, esrarkeşlerin düştükleri durumları ve hâlleri tasvir ederek, esrarkeşlerin genellikle toplumdan dişlanan kişiler olduğunu kendine has edebî üslubuyla anlatmaktadır. Ayrıntılı bilgi için bkz. Muallim Şövalye Hasan Bahri, age., s. 1-10.

${ }^{55}$ Abdülaziz Bey, age., s. 328.

56 Abdülaziz Bey'in gözlemlerine göre Osmanlı Döneminde İstanbul'da yaşayan esrarkeşler içinde Dersaadet ve diğer yerlerden kimseler varsa da çoğu Halep, Suriye, Beyrut ve havalisindendi. Abdülaziz Bey, age., s. 328-329.
} 
uyuşturucular üretilmesidir. ${ }^{57}$ Bunlar içerisinde morfin, eroin ve kodein gibi kimyasalların sahneye çıkması, dünyada uyuşturucu madde tiryakiliğine farklı bir boyut kazandırmıştır.

Dünyada özelikle Batı'da XIX. yüzyılın sonuna doğru yeni sentetik uyuşturucuların bağımlılık özelliğinin farkına varılması, madde bağımlılığını artık modern tıbbın da konusu hâline getirmiş ve madde bağımlılığı tedavi edilmesi gereken bir hastalık olarak değerlendirilmeye başlanmıştır. ${ }^{58} \mathrm{Bu}$ durum Osmanlı toplumu için de geçerliliğini korumuş olup algılama sorunları, hafıza bozuklukları, sersemlik ile güçsüzlük gibi çeşitli bilişsel ve fizyolojik problemlerin afyon ve esrar ile bunlardan elde edilen sentetiklerin kullanımından kaynaklandığ 1 , XIX. yüzyılın son döneminde daha fazla vurgulanmaya başlamıştır. ${ }^{59}$ Nitekim Osmanlı arşiv kaynaklarında elde edilen bilgilere göre akli denge sorunları olduğu düşünülen birçok kişinin, aslında başta esrar olmak üzere eroin, kokain ve morfin gibi uyuşturucu maddeleri kullanmaktan dolayı rahatsızlık yaşadıkları belirtilerek, devletin denetim rolüne vurgu yapılmaktadır. ${ }^{60}$

XIX. yüzyılın ikinci yarısından itibaren yeni uyuşturucuların sahneye çıkmasıyla birlikte uyuşturucu madde kullanımının yaygınlaşması, dünyada uyuşturucu kullanım meselesinin bağımlılık ekseninde değerlendirilmesine yol açmıştır. Bu çerçevede XX. yüzyılın başlarından itibaren özellikle dünya genelinde uluslararası sözleşmelerle uyuşturucu üretim ve ticaretinin kontrol altına alınmasına çalışılmış, hemen her devlette uyuşturucuyla mücadeleye dair kanunlar çıkarılmıştır. ${ }^{61}$ Uluslararası antlaşmalarla uyuşturucu madde kullanımıyla yasal yollardan mücadele, Osmanlı Devleti için de geçerliliğini korumuş olsa da aslında Osmanlı Devleti'nin afyon ve esrar başta olmak üzere uyuşturucu maddelerle mücadelesi çok daha eski tarihlere dayanmaktaydi.

\section{Uyuşturucu Madde Kullanımına Karşı Devletin Bazı Mücadele Çalışmaları}

Uyuşturucu maddeye kaynaklık eden afyon ve esrar, eski medeniyetlerde olduğu gibi İslam medeniyet havzasında öncelikli olarak tedavide ve ilaç yapımında kullanıma sahip olduğu için kamu otoriteleri ve toplumun geneli tarafindan uyuşturucu maddelere başlangıçta olumsuz bakılmamıştır. Ancak ilerleyen süreçte maddelerin keyif verici özelliklerinin farkına varılması, afyon ve esrara karşı daha titiz bir bakış açısının gelişmesine ve mücadele politikalarının hayata geçmesine imkân sağlamıştır.

Uyuşturucu maddenin keyif amacıyla kullanımına dair İslam dünyasındaki ilk örnekler, İslam dininin doğuşundan sonraki yüzy1llara tekabül etmektedir. Kutsal kitapta uyuşturucu maddeyle ilgili hükümlere rastlanmamasına rağmen toplumda keyif amacıyla kullanıma dair örneklerin ortaya çıkması, meselenin fikıhçıların gündemine girmesini sağlamıştır. Böylece uyuşturucu maddelere karşı mücadele edilmesi gerektiği vurgulanmaya başlanmıştır. ${ }^{62}$ Uyuşturucu maddelerle mücadele edilmesi yönünde İslam toplumlarında geçerli olan bu bakış açısı, aynı şekilde Osmanlı toplumunda genel kabul görmüş, bilhassa afyon ve benc gibi uyuşturucu maddelerin tedavi dışında keyif verici olarak tüketimine karşı mücadele politikaları

\footnotetext{
${ }^{57}$ Başoğlu, agm., s. 250.

${ }^{58}$ Kılıç, agm., s. 163.

${ }^{59}$ Eyüp Talha Kocacık ve Afife Mat, “İstanbul'da Zehirler ve Zehirlenme Vakaları”, Osmanlı Bilimi Araştırmaları, XV/2, 2014, s. 31.

60 BOA, Zabtiye (ZB), nr. 490/88, 26/RA/1324 (20/05/1906); BOA, Dâhiliye Nezareti Emniyet-i Umumiye Tahrirat Kalemi (DH.EUM.THR.), nr. 22/19-0, 29/Z/1328 (03/01/1911).

${ }^{61}$ Başoğlu, agm., s. 250; Kılıç, agm., s. 163.

62 İslam toplumlarında uyuşturucu maddelerin sağlık açısından zararlarından ilk bahsedenlerin başında İbn-i Sina gelmektedir. İbn-i Sina, uyuşturucu maddeler içerisinde özellikle afyonun zekâyı körelttiğini, bilinci bozduğunu, sindirim sistemini zayıflattığını ve nihayetinde ölüme yol açtı̆̆ını ifade etmektedir. Yine İbn-i Sina ile hemen hemen aynı dönemde yaşamış olan Biruni de afyonun derin uyku ve ölümlere sebebiyet verdiğini, özellikle sıcak bölgelerde yaşayan insanların kolay uyumak ve kendilerini rahatlatmak için buna tevessül ettiğini, ancak bunun hekimler tarafından hastalara kullanılmak yerine keyif amacıyla kullanılmasının ölüme sebebiyet verdiğini ifade etmektedir. Bunun için de İslam toplumları için endişe ettiğini ve dikkatli olunması yönünde topluma uyarılarda bulunmaktadır. Ayrıntılı bilgi için bkz. Hamarneh, agm. s. 230-231; Baktır, agm., s. 442; Başoğlu, agm., s. 249.
} 
benimsenmiştir. ${ }^{63}$ Uyuşturucu madde vasfı taşıyan maddelerle devletin mücadele çalışmaları ise kendini öncelikli olarak adalet, idare, iktisat, sağlık gibi toplumu ve devleti doğrudan ilgilendiren alanlarda göstermiştir.

\subsection{Adli-İdari Alanda Mücadele Çalışmaları}

Osmanlı devlet sistemi kendi içinde bütünlük arz eden yapısıyla dikkati çekmektedir. Bu yapı dâhilinde siyasi, dinî, askerî, mali, idari ve hukuki alanda bir mesele ortaya çıktığında karar verme merciinde olan birimler, ilgili alanları göz önünde bulundurarak bir karara varmak durumundaydılar. Devletin bu bütüncül bakış açısını bazı devlet yetkililerinin görev ve sorumluluk tanımları içerisinde görmek mümkündü. Örneğin kadıların adli görevlerinin yanında mülki, beledî, mali, askerî sorumluluklarının bulunması bunun göstergelerindendi. ${ }^{64}$

Osmanlı sisteminin bütüncül bakış açısı, uyuşturucu madde gibi devleti ve toplumu yakından ilgilendiren meselelerde karşımıza çıkmaktadır ve bu bağlamda birçok alanda olduğu gibi özellikle adli ve idari mekanizmaları birbirinden bağımsız düşünmemek icap etmektedir. Çünkü uyuşturucu madde kullanımı gibi devleti ve toplumu tehdit eden bir sorun karşısında önce hukuki bir karar verilmesi, arkasından da verilen kararın idari birimlerce titizlikle uygulanması, güçlü bir devlet ve hukuk sistemini gerekli kılmıştır.

Osmanlı hukuk sistemi çerçevesinde uyuşturucu madde meselesine bakıldığında devlet yönetimi tarafından madde kullanımı, dinî içtihatlara göre haram kabul edildiği için buna, adli ve idari birimlerce müsamahalı bir yaklaşım sergilenmemeye çalışılmıştır. Bundan dolayı kaynağını İslam hukukundan alan Osmanlı hukuk sistemine göre uyuşturucu özelliği taşıyan afyon, esrar gibi maddelerin keyif amacıyla kullanımı, suç ve ceza siyaseti çerçevesinde ele alınmıştır. Nitekim madde kullanımı, bazı fikıhçılara göre had cezası olarak kabul edilse de çoğunluğun görüşüne göre ta'zîr cezasını gerektiren bir fiil olarak değerlendirilmişti. ${ }^{65} \mathrm{Bu}$ doğrultuda uyuşturucu özelliği taşıyan maddelerin İslam hukuku açısından titizlikle değerlendirildiğini Osmanlı Devleti'nde şeyhülislam fetvalarında görmek mümkündür. Bunlar içerisinde XVI. yüzyılın ilk yarısında şeyhülislam olan İbn Kemal, afyon ve esrarın sağlık amacı dışında keyif verici olarak kullanmanın haram olduğunu, bunları içen ve satanlara ta'zîr cezaları verilmesi gerektiğini vurgulamıştır. ${ }^{66}$ Yine XVI. yüzyılın ikinci yarısının önemli ismi

\footnotetext{
${ }^{63}$ Başoğlu, agm., s. 249; Baktır, agm., s. 442.

${ }^{64}$ Mehmet Genç, Osmanlı İmparatorluğunda Devlet ve Ekonomi, 4. Bask1, Ötüken Yay., İstanbul 2005, s. 43-44. Osmanlı kadısının mülki, beledî, mali, askerî ve adli sahaları kapsayan görevleri göz önüne alınırsa onun kadar geniş bir görev alanı bulunan bir başka memur olmadı̆̆ı gibi memuriyet kompartımanı ve şahsiyeti onun kadar çeşitli olanı da yoktur denebilir. Kadı, ilmiye sınıfındandır, şerî hukuk adamıdır, ancak mülki erkân içindedir. Bütün yönetici zümre gibi ayrıca askerî sınıfın bir üyesidir (vergiden muaf yönetici imtiyaz ve yetkileri vardır), fakat bir yerde yönettiği Müslüman halkın dahi merkezî devlet karşısında sözcüsü yine odur. İlber Ortaylı, "Kadı", İslam Ansiklopedisi, C. 24, TDV Yay., İstanbul 2001, s. 69-70.

${ }^{65}$ Fakihler, uyuşturucu maddelerin haramlığında ittifak etmekle birlikte hükmün illeti ve delillendirilmesi yönünden farklı kanaatlere sahiptirler. İbn Teymiyye ve Zerkeşî gibi birçok alim esrar, afyon vb. uyuşturucu maddeleri şaraba kıyaslamış, onların da sarhoş edicilik vasfına dikkat çekerek, "Her müskir haramdır." hadisi kapsamında esrar ve afyonun da gevşeklik veren ve uyuşturma özelliklerinden dolayı cezayı gerektirdiğini belirtmişlerdir. İbn Teymiyye ve ondan sonra gelen Hanbelîler adı geçen maddelerin sarhoş etmeyecek kadar az miktarda alınsa bile had cezası (içki haddi) verileceğini ve helal görenlerin tekfir edileceğini söylerler. Ancak İbn Teymiyye benc kullanımını haram saymakla birlikte müskir maddelerden addetmez ve onu kullanan için ta'zîr cezası öngörür. Buna karşı Maverdi (ö. 450 / 1058) ve İbn Âbidîn (ö. 1252 / 1856) gibi düşünen ve çoğunluğu oluşturan âlimler ise siv1 olmayan ot türü maddeleri kullananlara içki içme haddine kıyas yapılarak had cezası verilemeyeceğini, ancak ta'zîr cezası verilebileceğini belirtirler. Başoğlu, agm., s. 251; Şükrü Özen, "Tütün (F1kıh)", İslam Ansiklopedisi, C. 42, TDV Yay., İstanbul 2012, s. 7; Kibar Karadeniz, Bağımlılık Yapan Madde Kullanma Suçlarının İslam Hukuk Sosyolojisi Açısından Değerlendirilmesi, Yayımlanmamış YLT, Ankara Ü. SBE, Ankara 2009, s. 46-47.

${ }^{66}$ Şeyhülislam İbn Kemal'e göre afyon yemek keyif için olmadığı ve sekir sınırına ulaşmadığı müddetçe yasak değildir. "Esrar helal midir haram midır beyan oluna? Cevap: Hadd-i sekre varmayınca haram olmaz. Hadd-i sekr nedir ne mertebedir beyan oluna? Cevap: Tağyir vaz edip hezeyan söylemek". "Afyonun yemesi helal midir? Cevap: Helaldir. Esrarın kalil ve kesiri keyfiyet için yemek helal midir? Cevap: Haramdır". "Afyon suyuyla macunlar düzüp dahi ecza katıp, hap düzüp yeseler şer'an helal eda var mı keyfiyet içinde yeseler? Cevap: Keyfiyet
} 
şeyhülislam Ebüssuûd Efendi de uyuşturucu kullanımının menedilmesi, kullananlara ta'zîr cezaları verilmesi ve suç unsuru maddelerin derhâl imhası yönünde fetvalar vermiştir. ${ }^{67}$

Şeyhülislamların afyon ve uyuşturucu özelliği olan madde kullanımının sakıncaları ve bunların temin edildiği ortamlara dikkat edilmesi gerektiği yönündeki görüşlerine rağmen uyuşturucu özelliği olan maddelerin kullanımının görülmesi, özellikle XVI. yüzyılın ikinci yarısında merkezi devlet yöneticilerini daha katı tedbirler almaya yöneltmişti. Bu noktada şeyhülislamların şeri hukuk sistemine dayanan fetvalarıyla birlikte afyon, beng ve berş gibi maddeleri kullananlarla, kullandıranların ta'zîr cezaları kapsamında kürek başta olmak üzere hapis, sürgün ve siyaseten katl'e varıncaya kadar çeşitli cezalara tabi tutulmaları, XVI. yüzyılın ikinci yarısına ait arşiv belgelerinde dikkati çeken hususlar arasındadır. ${ }^{68}$

Osmanlı Klasik Dönemi'nde uyuşturucu maddelere karşı suç ve ceza yaklaşımında önemli bir dönem de XVII. yüzyılın ilk yarısında padişah olan IV. Murad devridir. Nitekim IV. Murad, fazla dozda afyon alındığı takdirde bu maddenin insanı sarhoş ettiğini öğrenince, afyon başta olmak üzere bağımlılık yaptığı bilinen bütün maddeleri tebaasına anında yasak ettirmişti. ${ }^{69}$ Ayrıca Padişah bununla da sınırlı kalmayarak daha önceki yüzyıllarda olduğu gibi uyuşturucu maddelerin mekânsal kaynağı olarak gördüğü İstanbul'daki kahvehanelerin de kapatılmasına, kapatma yasağına uymayanların daha şiddetli cezalandırılmasına karar vermişti. Ancak bütün yasaklamalara rağmen özellikle afyon tiryakiliği, toplumun bir kısmında görülmeye devam etmişti. Çünkü cezai yaptırımlara rağmen hem haşhaş üretiminin Anadolu'nun çeşitli yerlerinde yaygın oluşu hem yasaklamalara rağmen kaçak yollardan da olsa kahvehane alışkanlığının devam etmesi hem de bu mekânlarda uyuşturucu kullanımının geçmişten beri düzenli bir faaliyet olarak algılanması, kullanım sorununu tamamen ortadan kaldıramamıştır. ${ }^{70}$

için yemek helal değildir". Ayrıntılı bilgi için bkz. Ali Öge, "Şeyhülislam İbn Kemal’in Fetvaları Işı̆̆ında Osmanlı İktisâdî Hayatından Bir Kesit”, İslam Hukuku Araştırmaları Dergisi, S. 16, 2010, s. 294.

67 "Esrarı keyfiyet için yiyecek, kalilen ve kesîren haram midır? Cevap: Haramdır". "Esrar ekl eden kimseye şer'an ne lazım olur? Cevap: Ta’zîr-i şedîd lazımdır”. M. Ertuğrul Düzdă̆, Şeyhülislâm Ebûssuud Efendi Fetvaları Işığında 16. Asır Türk Hayatı, Enderun Kitabevi Yay., İstanbul 1972, s. 145; Ahmet Yaşar, "Külliyen Ref'ten “'İbreten Li'l-Ğayr'e: Erken Modern Osmanlı'da Kahvehane Yasaklamaları”, Osmanlı Kahvehaneleri: Mekân, Sosyalleşme, İktidar, ed. Ahmet Yaşar, Kitap Yay., İstanbul 2010, s. 38-39.

68 "Menteșe beğine hüküm ki: Balat kâdîsı mektûb gönderüp; 'Abdülcebbâr nâm kimesnenün karındaşl olan Abdülazîz'ün Abdülkâdir oğlı Abdüsselâm nâm kimesne kulağına jiva koyup ve afyon ezüp içürüp andan fevtolmışdur.' diyü da 'vâ itmeğin mezbûr Abdüsselâm'un ikrârı sâbit olup müseccel olmışdur." diyü bildürmeğin buyurdum ki: Mezbûrı kayd ü bend ile yarar âdemlere koşup sûret-i sicilli ile Südde-i Sa'âdetüm'e gönderesin ki, küreğe konıla ve bile koşup gönderdügün âdemlere tenbîh ü te'kîd eyleyesin ki, yolda ve izde kaçurmakdan hazer ideler”. BOA, 7 Numaralı Mühimme Defteri 975-976/1567-1569, C. I, nr.1012, 417, Dîvân-1 Humâyûn Sicilleri Dizisi: V, Devlet Arşivleri Genel Müdürlüğü Yay., Ankara 1998, Hüküm nr. 178, Fî 15 Rebî’u’l-evvel, sene: 975 (1567); Yine bu dönemde benzer bir hüküm de şöyledir: "Bursa kadısına hüküm: Zımmilerin Müslümanlara şarab satmasının, sade-ru oğlanların perişanı tülbendler sarınup ve mütenevvi libaslar giyinip levendlerle gezmesinin ve fasıklar mecmal olan kahvelerin kapatılıp kahve içinde berş, macun, beng ve afyon alınmak ve ekseriya kahve bahanesiyle şarab ve rakı içilmek ve nerd, satranç ve tavile ve kumar oynanmak suretiyle iş sahiblerinin atalette ve ilim taliblerinin cehalette kalmalarının ve eracif haberler aldırma önü alınması hakkında cülustan beri mükerreren verilen emirlerle mukayyed olunmadiğından bu kere de emrin icrasında teallül eden olursa cezasının verilmesi mukarrer olduğu bilinerek münadilerle yapılacak tenbihata riayet etmeyenleri ve onlara müsamaha eden subaşı ve asesleri küreğe konulmak üzere İstanbul'a göndermesi, kuzat ve müderrislerden ve mansı ve dirlik mutasarrıflarından itaat etmeyenlerin isimlerinin bildirmesi". Ayrıntılı bilgi için bkz. BOA, Divan-ı Hümâyun Mühimme Defteri (A.DVNSMH.d), nr. 35/225, 14/Rabiu'l-evvel (RA)/986 (21/05/1578). Yine uyuşturucu maddelerin kullanıldığı mekânlar olarak görülen kahvehanelerin ortadan kaldırılması hakkında Aydın beyine ve Tire kadısına hüküm hakkında bkz. BOA, A.DVNSMH.d, nr. 35/544, 26/Rabiu'l-ahir (R)/986 (02/07/1578).

${ }^{69}$ Osmanlı padişahı IV. Murat afyon ve tütün gibi bağımlılık yapıcı maddelere karşı sert önlemleriyle dikkat çekmekteydi ve padişahın ilk afyon kurbanı da Hekimbaşı Emir Çelebi'ydi. IV. Murat'ın Bağdat seferi sırasında yanında olan Emir Çelebi yanında taşıdığı afyon macununu gizli gizli kullanmakta idi. Bu durum Padişah'a bildirilmiş ve Padişah da Emir Çelebi'nin elbisesinin altında sakladığı afyon macununu bularak hepsini yedirtmiş ve o günün akşamı Emir Çelebi komaya girerek ölmüştü. Ayrıntılı bilgi için bkz. M. D’Ohsson, 18. Yüzyıl Türkiyesinde Örf ve Adetler, çev. Zehran Yüksel, Tercüman 1001 Temel Eser, Tarihsiz, s. 47-48.

${ }^{70}$ IV. Murad, 1633 tarihinde bütün kahvehanelerin kapatılmasını ve kahve içilmesini yasakladı. Sadece Haslar kadılığında 120 kahvehane kapatıldı. Ahmet Yaşar, agm., s. 39-40. 
Osmanlı Devleti'nde adli ve idari alanda mücadele çalıșmaları daha önceki yüzyıllarda olduğu gibi XVIII. yüzyılda da devam etmekteydi. Bu yüzyılda devletin afyon ve esrar konusundaki engelleyici tavrı devam etse de afyon kullanımı ve tiryakiliği halk arasında yayılmaya başlayınca devlet idaresi, 1723 (H 1136) yılında şeyhülislamdan fetva alıp daha kararlı bir şekilde afyon tiryakiliği yasağı ilan etmeye mecbur kalmıştı. Bunun sonucunda halk arasında bilinen ne kadar afyon tiryakisi varsa hepsi toplanarak taşrada birer tarafa sürülüp dağıtılmıştı. ${ }^{71}$ Yine afyona benzer özellikler taşıyan esrar için de yasaklamalar ve cezalar yürürlüğe girmişti. Özellikle esrar tiryakilerine küreğe konulma ve sürgün gibi caydırıcı ceza yöntemleri uygulanmaya çalışılmış, yerel yöneticiler de bu konuda yasağı titizlikle uygulaması hususunda uyarılmışlardı. ${ }^{72}$

Osmanlı toplumunda uyuşturucu özelliği taşıyan afyon ve esrarın keyif amacıyla kullanımına karşı XVII. ve XVIII. yüzyıllarda uygulanan müdahaleci tutum, XIX. yüzyılda da devam etmişti. Bu doğrultuda Dâhiliye Nezareti tarafından 1851 yılında taşradaki birimlere gönderilen bir talimatta, esrar tabir edilen maddenin kullanımının ve satışının yasaklanmış olduğu vurgulanarak, yerel yöneticiler yasağa müsamaha göstermemesi hususunda uyarılmıştı. ${ }^{73}$ Yine XIX. yüzyılın ikinci yarısında esrar kullanımını önlemeye yönelik çabalar çerçevesinde özellikle satış yapanlara yönelik ağır sayılabilecek cezaların uygulandığı dikkati çekmektedir. Uygulanan cezaların başında ise hapis, sürgün ve zorunlu olarak kamu yararına çalışma cezaları gelmekteydi. ${ }^{74}$ Buna karşılık dünyada, özellikle İngiltere ve Amerika gibi gelişmiş ülkelerde bu dönemde afyon ve esrar kullanımının yasaklanması ve cezalandırılması gibi yöntemlere henüz gidilmemişti. $^{75}$

Uyuşturucu maddeye karşı mücadele çalışmalarında dünya ölçeğinde asıl gelişmeler, XX. yüzyılın başlarına tekabül etmektedir. Bilhassa haşhaş ve kenevirden elde edilen ürünlerin keyif amacıyla kullanımının özellikle şehir hayatında getirdiği sorunlar, dünyada ekonomik getirinin ikinci plana atılmasına gerekçe olmuştur. Sonrasında ise insanlık için gerekli olan bu maddenin

71 “Berş i’lâmı Ma'rûz-ı dầ'̂-i devletleridir ki: Bâ sah i’lâmları mûcebince amel olub bundan ziyâde verdikleri istimâl olunur ise ta'zîr olunmaların mukarrer bileler deyu buyruldu." İstanbul Kadı Sicilleri, İstanbul Mahkemesi 24 Numaralı Sicil, Belge nr. 20b-2, C. 21, TDV İSAM Yay., s. 131, 04/Zilkade (ZA)/1138 (4 Temmuz 1726); Reşad Ekrem Koçu, agm., s. 228-229.

721725 yılında Muharrem başlangıcında Edirne mollasına, bostancıbaşısına ve yeniçeri zabitine hitap eden ve bir örneği de İzmir'e gönderilmiş olan bir padişah emri yayımlanmaktadır. Bu emirde padişah, haşiş (esrar denilen ot) cinsinden gonca denilen bitkinin yakın zamanda tütün gibi içilmesine müptela olanların az zamanda akıl ve şuurlarına hafiflik ve zihnî tasavvur ve kuvvetlerini bozma ile çeşitli zararlar verdiğini, bundan başka, çok defa Bektaşi tarikatında bazı toy gençlerin hayalleri ile gördüğü garip şekilleri haşa sümme hâşa kerem ve şeref sahibi evliyaya vâki olan sırlar ve kerametler sandıklarını, böylece dinsizliklere sebebiyet verdiklerini bildirmekte, esrar içenlerden İstanbul'da yakalananların sürülüp ya da küreğe konulduklarını, böyle iken bu maddenin Edirne ve dolaylarında satıldığının işitildiğini, bu hususta çok dikkat gösterilmesini ferman eylemekteydi. Ayrıntılı bilgi için bkz. Cevdet Türkay, "Osmanlı İmparatorluğunda Yasaklar, Esrar Yasă̆ı”, Belgelerle Türk Tarihi Dergisi, C. XI, S. 64, 1973, s. 16; Mossensohn, age., s. 43-44. Bahçekapısı hamamında "beng” satan birinin Molova Kalesi'ne sürgün edilmesi hakkında bkz. BOA, Cevdet Zabtiye (C.ZB.), nr. 73/3613, 19/ZA/1179 (29/04/1766).

${ }^{73}$ BOA, Irade Dâhiliye (İ.DH), nr. 229/13732, 23/Cemaziye'l-ahir (C)/1267 (25/04/1851).

${ }^{74}$ Esrar kullanımının yasaklanarak, satanların cezalandırılması hakkında bkz. BOA, Sadaret Nezaret ve Devair Evrakı (MKT. NZD), nr. 77/17, 05/L/1269 (12/07/1853). Kahvesinde esrar içirmiş olan kahvehane sahiplerine hapis cezası verilmesi hakkında bkz. BOA, Meclis-i Vâlâ Riyâseti (MVL), nr. 179/59, 21/Ramazan (N)/1273 (15/05/1857); BOA, Sadaret Mühimme Evrakı (MKT. MHM), nr. 489/10, 20/N/1303 (22/06/1886). Farkl1 bir ceza yöntemi olarak dikkati çeken kamu yararına çalışma cezası kapsamında bazı esrar satıcıları da iplikhaneye zorunlu çalışmaya gönderilmişti. BOA, MVL, nr.179/53, 24/N/1273 (18/05/1857).

75 XIX. yüzyılda dünya politikasında belirleyici konumda bulunan İngiltere'de bile 1868 yılına kadar uyuşturucu özelliği bulunan maddelerin kullanımına yönelik herhangi bir kısıtlayıcı düzenleme söz konusu değildir. Bu yılda Eczacılık Kanunu'nun yürürlüğe girmesinden sonra afyon ve türevi ürünlerin eczanelerde belli bir kontrol altında satılmasına başlanmıştı. Dolayısıyla yüzyılın sonuna kadar uyuşturucu maddeler halk sağlığını ilgilendiren bir mesele olarak görülmediğinden, yasaklayıcı tedbirlere henüz başlanmamıştı. Kanun'un yürürlüğe girmesinden sonraki süreçte ise mücadele çalışmaları ivme kazanmaya başlamıştı. Ayrıntılı bilgi için bkz. Virginia Berridge, Opium and the People (Opiate Use and Drug Control Policy in Nineteenth and Early Twentieth Century England), London 1999, p. 118-121; Virginia Berridge, "Two Tales of Addiction; Opium and Nicotine", Human Psychopharmacology, Vol: 12, London 1997, p. 45-46; Bayraktar, agm., 1985, s. 50. 
sadece tıbbi alanda kullanılması ve diğer alanlarda yasaklanması yönünde dünyada yaygın bir kanaat hâsıl olmuştur. ${ }^{76}$ Bütün bu gelişmeler 1şığında XX. yüzyılın başında Amerika ve Avrupa'da keyif verici madde kullanım oranının artmasından dolayı ABD öncülügünde afyon ve alkaloitlerine karşı uluslararası alanda müdahaleler gündeme gelmiştir. $\mathrm{Bu}$ amaç doğrultusunda 1909 tarihli Şangay ve devamında Konferansı ve 1911, 1913 tarihinde de Lahey'de konferanslar düzenlenerek afyon ve türevi ürünlerin kısitlanmasına yönelik önlemler ile afyonun ticari durumu kontrol altına alınmaya çalışılmış, daha sonra idari yasaklamalar ve kısıtlamalar kendini göstermeye başlamıştı. ${ }^{77}$

Dünya ölçeğinde özellikle Batı toplumlarında XX. yüzyılın başlarından itibaren bağımlılık yaptığı tespit edilen maddelere yönelik idari ve hukuki perspektifle öne çıkan yasaklamalar ve kanunî düzenlemeler, zaten eskiden beri tedbirler alan Osmanlı Devleti'nde karşılığını bulmuştu. Bu süreçte afyon üretiminde önemli bir aktör olan Osmanlı Devleti'nin afyon üretimini ve ticaretini devam ettirme hususunda Batı ülkeleriyle aynı istikamette düşünmese bile keyif amacıyla kullanımı önleme noktasında aynı bakış açısına sahip olması, gelişmiş Batı ülkeleri için önemliydi. Çünkü Orta Doğu ve Uzak Doğu'dan imal edilerek Avrupa'ya hatta Amerika'ya taşınan maddelerin transit geçit bölgesinde yer alan Osmanlı topraklarının bu süreçte sıkı şekilde kontrol altına alınması gerekiyordu. Nihayetinde Osmanlı idari birimlerinin de özellikle Akdeniz'e komşu ve transit geçit bölgelerinde bulunan yerlerde denetimlerini arttırdıkları görülüyordu. ${ }^{78}$ Yine bu dönemde Osmanlı Devleti sadece Orta Doğu

\footnotetext{
${ }^{76}$ Sanayi Devrimi sonrasında ortaya çıkan şehirleşme ve toplumsal sorunlarla birlikte özellikle İngiltere'de sayıları hızla artan işçi sınıfı, XX. yüzyılın başlarında ekonomik nedenlerle alkol yerine daha ucuz yollarla temin ettikleri afyon ve afyon türevi ürünleri kullanmaya yönelmişti. Bu durum sadece İngiltere özelinde değil, Kıta Avrupası'nda ve Amerika'nın sanayi şehirlerinde de artmaya başlamış, şehirlerde ekonomik, sosyal, asayiş ve sağlık gibi sorunlara neden olmuştu. Diğer taraftan Almanya'da üretimine başlanan eroin maddesinin Avrupa başta olmak üzere Amerika'da kısa sürede keyif amacıyla kullanılmaya başlaması ve ileri derecede bağımlılık yaptığının tespit edilmesi üzerine mücadele politikaları kendini göstermeye başlamıştı. Bu doğrultuda 1920 yılında İngiltere, Tehlikeli Uyuşturucular Yasası'nı çıkartarak tıbbi olmayan amaçlar dışında eroin üretmeyi, satmayı ve dağıtmayı ceza gerektiren bir suç hâline getirmiş, bu tür yasaklar diğer Avrupa ülkelerinde de hayata geçmeye başlamıştı. Ayrıntılı bilgi için bkz. Berridge, "Two Tales of Addiction; Opium and Nicotine", s. 47; Seddon, agm., s. 143. Avrupa'da görülen bu gelişmelerin yanı sıra ABD'de ise XIX. yüzyılın son çeyreğine doğru afyon türevlerinden elde edilen uyuşturucuların yayılması üzerine kamuoyunda iki grup suçlanmaya başladı. Bunlar; Çinliler ve doktorlardı. Çünkü afyonun anavatanı olarak Uzak Doğu gösteriliyordu ve Çinli göçmenlerin ABD’ye uyuşturucu taşıdıkları söyleniyordu. Ayrıca bu süreçte doktorlar da ağrı kesici olarak afyon ve opiatlarını reçetelerle sık şekilde vermeye başlamışlardı ve bunun da uyuşturucu kullanımına zemin hazırladığı iddia ediliyordu. Nitekim sorunun büyümeye başlaması üzerine ABD'de ilk defa 1875 yılında San Francisco Afyon Yönetmeliği çıkarılarak afyon ve türevi ürünlerin denetim altına alınması sağlanmaya çalışılmıştı. Daha sonra kısıtlama ve yasaklama yolundaki politik bakış açısı devam ederek süreç, XX. yüzyılın başlarından itibaren afyon konferansları ve uluslararası yasaklamalara kadar gitmişti. Ayrıntılı bilgi için bkz. Stevens, age., s. 7-8.

${ }^{77} \mathrm{XX}$. yüzyılın başlarında uyuşturucu ve bağımlılık yapıcı özellikleri bilinen afyona karşı bu dönemde İngiltere ve ABD farklı yaklaşımlara sahiptirler. İngiltere kendisine bağlı sömürge olan ve Hindistan üzerinde uyuşturucu maddeler içerisinde özellikle esrar ve afyon üzerinde önemli bir gelir elde ederken, ABD bunu bir halk sağllğı problemi olarak görerek yasaklama suretiyle doğrudan arzı ortadan kaldırmayı amaçlamıştı. Bu süreçte İngilizler ise doğrudan yasaklama yerine, talebi azaltmaya yönelik çabalar içerisine girilmesi gerektiğini düşünmüştü. 1909 tarihli Şangay Konferansında bu minvalde gelişen süreç, 1925 tarihli Cenevre Konferansında da devam etmiş ve İngiltere'nin karşı çıkmasına rağmen ABD'nin çabalarıyla esrar da uluslararası yasaklar listesine girmişti. Ayrıntılı bilgi için bkz. Stevens, age., s. 8. Ayrıca Türkiye'nin tutumu hakkında bkz. Suna Altan, "Cenevre Afyon Konferansları ve Türkiye'nin Tutumu", Çanakkale Araştırmaları Türk Yıllı̆̆ı, Bahar 2019, S. 26, s. 49-51.

${ }^{78}$ XX. yüzyılın başlarından itibaren uyuşturucu özelliği bulunan maddelerin kullanımına ve özellikle bunların transit ticaretinin önüne geçmek üzere Doğu Akdeniz'de asayiş tedbirlerinin daha da sıklaştırıldığı dikkati çekmektedir. Bu kapsamda İskenderiye Gümrügü̈nde yakalanan esrardan dolayı sorgulanması gereken kişilerin mahkemeye gönderilmesi hakkında BOA, Hariciye Nezareti Hukuk Müşavirliği İstişare Odası Evrakı (HR.HMŞ.IŞO), nr.186/71, 24/RA/1316 (12/08/1898). Beyrut'ta alınan tedbirler sonucu esrar yakalanması ve bununla ilgili olan şahısların mahkemeye sevki hakkında BOA, Dâhiliye Nezareti Şifre Kalemi (DH.ŞFR), nr. 342/81, 07/ZA/1321 (26/01/1904); Müsadere edilen esrarların imha edilmesi gerektiğinden Tobruk sahilinde ele geçirilen esrarın usul ve kaidesince imha edilerek düzenlenen evrakının Rüsumat Emanetine gönderilmesi hakkında BOA, Dâhiliye Nezareti Mektubî Kalemi (DH.MKT), nr. 780/50, 07/CA/1321 (01/08/1903); Esrar ve tönbekü yüklü vapurların Trablusşam açıklarında bulunması ve yetkililerin bu mallara bir an evvel el koymaları hususunda BOA, Dâhiliye Nezareti Şifre Kalemi (DH.ŞFR), nr. 414/85, 10/Rabiu'l-ahir (R)/1325 (23/05/1907); BOA, DH.MKT, nr. 2836/30, 28/R/1327
} 
topraklarında değil, Anadolu ve İstanbul başta olmak üzere diğer bölgelerde de keyif amacıyla kullanıma karşı mücadele ediyordu. Bu çerçevede XX. yüzyılın başından Cumhuriyet'e devam eden süreçte uyuşturucu maddelerin yurt içinde kullanımını ve satışını önleme çabaları kapsamında devletin yasaklama ve asayiş tedbirleri, adli ve idari birimlerce önemli bir kesintiye uğramadan sürdürülmeye çalış1lıyordu. ${ }^{79}$

\section{2. İktisadi Alanda Mücadele Çalışmaları}

Osmanlı toplumunda uyuşturucu maddeye kaynaklık eden haşhaş ve kenevirden elde edilen ürünler, kendi içinde belli bir arz ve talep piyasasına sahiptir. Bu ürünler, öncelikli olarak sağlık alanında şifa kaynağı ve ağrı kesici ürünler olarak bir piyasaya sahip olduğu için bir gelir kaynağı olarak görülmüştür. Ayrıca ürünler üzerinden alınan vergiler devlet hazinesinin gelir kaynakları arasında yer aldığı için de haşhaş ve kenevir ürünlerinin üretim, pazarlama-satış ve tüketim süreci, Osmanlı Devleti'nin iktisadi politikaları ile yakından ilgili olmuştur.

Osmanlı Devleti'nde uyuşturucu özelliği taşıyan maddelerin pazarlama ve satış süreci, yüzyıllar boyunca Osmanlı ticaret sisteminin temelini teşkil eden esnaflık örgütlenmesine göre şekillenmişti. Osmanlı esnaflık teşkilatına göre kendi içinde tutarlılığı olan bu sistemde herhangi bir aksaklık yaşanmaması için devletin ve esnaf teşkilatının ilgili birimleri, belli mal ve hizmetleri esnaf tekellerine bırakmıştı. Bu kapsamda afyon ve esrar gibi ürünlerin başkentte ticaretini tekeli altında bulunduran afyoncu ve benglikçi (esrarcı) esnafı, özellikle Osmanlı Klasik Dönemi'nde bu maddelerin alış ve satış işlemlerinde yetkili esnaflar olarak işlev görmüştü. ${ }^{80}$ Ayrıca afyoncu ve benglikçi (esrarcı) esnafina ek olarak, uyuşturucu özelliği taşıyan ürünlerle ilgili bir de macuncular esnafı vardı ki macuncular esnafı tarafından afyon karışımı olarak imal edilen ve satılan ürünler, yurt içinde belli bir pazara sahipti. ${ }^{81}$

(19/05/1909). Bölgedeki bütün önlemlere rağmen esrar kaçakçılığı sorununun devamı üzerine Cebel-i Lübnan ve Sayda civarına yeni karakolların yapılmasına karar verilmişti. BOA, Dâhiliye Emniyet-i Umumiye Emniyet Şubesi Evrakl (DH.EUM.EMN), nr. 113744, 07/C/1332 (03/05/1914).

${ }^{79}$ Anadolu coğrafyasında uyuşturucu maddeler içerisinde bir ticari mal olarak afyonun keyif amacıyla mı ticari bir ürün olarak mı kullanıldığını tespit etmek zor bir konuydu. Çünkü afyon önemli bir ihraç ürünüydü ve ticari olarak devlet tarafindan destekleniyordu. Ancak afyonun keyif amacıyla kullanımı doğal olarak yasaktı. Bundan dolayıdır ki afyonun ticari olarak mı keyif amacıyla mı kullanıldığını tespit etmek zor bir konu iken, kenevirden elde edilen esrarın keyif amacıyla kullanıldığını tespit etmek ve gerekli yaptırımları uygulamak devlet açısından daha kolaydı. Nitekim Anadolu'da esrar kaçakçılı̆̆ 1 ve kullanımının önlenerek esrar ve esrar tohumlarının zabıta ve rüsumatça derdestiyle imha edilmesi ve bunun bir cezaya karşılık geldiği ve bu cezanın da paraya çevrilemeyeceği hususunda bkz. BOA, Dâhiliye Nezareti Tesri-i Muamelât ve Islahat Komisyonu (DH.TMIK.M), nr. 168/9, 23/ZA/1322 (29/01/1905); BOA, Dâhiliye Nezareti İdare Evrakl (DH.ID), nr. 87/30, 05/CA/1329 (04/05/1911), BOA, DH.MKT, nr. 946/6, 11/Z/1323 (06/02/1906). Alınan asayiş önlemleri kapsamında özellikle geçmişten beri kullanımının yoğun olduğu İstanbul'da Tahtakale ve Sultanahmet civarındaki kahve ve evlerde belli aralıklarla esrar aramas1 yapılmaktaydı. BOA, Zabtiye Nezareti (ZB), nr. 308/50, 13/RA/1323 (18/05/1905). Ayrica cezaevlerine de kaçak yolardan esrar başta olmak üzere çeşitli uyuşturucu maddelerin sokulduğu ve bu meselede ihmali olan idareciler hakkında idari ve adli işlemlerin başlatıldığı dikkati çekmekteydi. BOA, Dâhiliye Nezareti Mebâni-i Emiriye Hapishaneler Müdüriyeti Müteferrik Evrakı (DH.MB.HPS.M), nr. 46/17, 02/Muharrem (M)/1339 (16/09/1920); BOA, DH.MB.HPS, nr. 165/76, 04/M/1338 (29/09/1919).

${ }^{80}$ Turhan Baytop, agm., s. 432; BOA, Cevdet Maliye (C.ML), nr. 450/18215, 08/C/1198 (29/04/1784).

${ }^{81}$ Osmanlı Klasik Dönemi'nde şifa ve ilaç maksadıyla üretilen pek çok macun türü vardı. Ancak bunlar içerisinde özellikle "Rahîkî macunu" XVI. yüzyıldan itibaren büyük bir üne kavuşarak İstanbul dışına da satışı yapılan bir ürün hâline gelmişti. Bu macun türünün uzunca süre varlığını devam ettirmesinde devletin yetki vermiş olduğu esnafı koruyucu ve destekleyici tavrı önemliydi. Çünkü devlet, bu macunda kalitenin bozulmaması, kontrolsüz şekilde yetkisiz kişilerce üretim ve satış yapılmasını engellemek ve amacı dışında keyif verici olarak kullanılmasını önlemek için üretme ve satma yetkisini Mahmutpaşa'da sadece iki dükkâna vermiş, bu dükkânların fiyatlarını da denetim altında tutmaya gayret etmişti. Nitekim bir kadı sicilinde bu durum şöyle ifade edilmektedir: "İstanbul'da vâki' Mahmud Paşa sükûnunda berş tabh ve bey' eden rahîkînin iki bâb dükkânlarından mâ'adâ mahmiye-i mezbûrede berş tabh ve bey' eden muhdes dükkânlar ta'til ve tabhdan men' olunmaları bâbinda bundan akdem tuğrâ-yı garrâ ile mu'anven sâdır olan fermân-ı âlîşân mûcebince zikr olunan iki bâb rahîkî dükkânlarından mâ'adâ muhdes olan dükkânlar men' ve ta'til olunmak takrîbiyle Memâlik-i Mahrûse'de bey' ü şirâ olunan berş ancak zikr olunan iki bâb dükkânlara maksûr olmağın... " İstanbul Kadı Sicilleri, İstanbul Mahkemesi 24 Numaralı Sicil, Belge No: 20b-2, C. 21, s. 131, 04/ZA/1138 (04/07/1726). Ayrıca Berş-i Rahîkî macunu hakkında ayrıntılı 
Osmanlı Klasik Dönemi'nde afyoncu, benglikçi ve macuncular adındaki esnaf zümrelerinin uhdesine verilen ve sağlık alanındaki kullanımından dolayı toleranslı yaklaşım sergilenen uyuşturucu özelliği taşıyan bu ürünlerin alış ve satış işlemlerindeki en riskli hususu, maddelerin keyif amacıyla kullanımı oluşturmaktadır. Bundan dolayı özellikle başkent İstanbul'da birer arz merkezi olarak kabul edilen "Tiryakiler Çarşısı" ve burada yer alan dükkânlar ile Mahmutpaşa civarındaki macuncular esnafı dükkânları, Osmanlı Devleti'nin esnaf nizamı çerçevesinde gerek mülkiyet yapısı gerek üretim açısından sık sık denetlediği yerler olarak dikkat çekiyordu. ${ }^{82}$ Dolayısıyla Osmanlı Devleti'nde iktisadi alanda uyuşturucu kaynağ 1 maddelerle mücadelenin devlet açısından dikkate değer unsurunu, arz meselesi oluşturuyordu ve arzın kontrol altına alınmasının da keyif amacıyla kullanımla mücadele açısından önemli olduğu kabul ediliyordu. ${ }^{83}$ Diğer taraftan devlet, özellikle afyonlu macun veya şurup imalatı yaparak keyif amacıyla kullanıma yönelik satış yapan dükkânları kapatırken, dükkânı kapatılan esnaf içerisinde 1slah olduğu gözlenenleri de başka bir iktisadi faaliyet koluna yönlendirmek suretiyle hem esnafın ișsiz kalmasını önlemeye hem de toplumun ihtiyacına cevap vermeye çalıșıyordu. Nitekim kaynağını Osmanlı esnaflık sisteminden alan ve sağlık amacına yönelik olarak uyuşturucu madde özelliği taşıyan ürünlerin üretim, satış ve dağıtımında bir nizamı öngören bu mekanizmanın XVIII. yüzyı sonlarına kadar önemli bir değişikliğe uğramadan varlığını sürdürdüğü görülmekteydi. ${ }^{84}$

Osmanlı coğrafyasında haşhaş ve kenevir bitkisinin ekonomik açıdan değer kazandığı asıl dönemin XIX. yüzyılın başları olduğu anlaşılmaktadır. Özellikle bu yüzyılın başında Avrupa'da uyuşturucu özelliği bulunan yeni ilaçlar ve ağrı kesicilerin imal edilmesi, haşhaş ve kenevir bitkisinin daha önemli hâle gelmesini sağlamıştır. Bunlar içerisinde bilhassa afyonunun sentezlenmesi suretiyle morfinin keşfedilmesi ve diğer ülkelere ait afyon çeşitlerinin \%8-10 oranında morfine sahip olmalarına karşılık özellikle İzmir bölgesi Osmanlı afyonlarının \%13-15 oranında morfin ihtiva etmesi, Avrupa ilaç sanayisinin Osmanlı ürünlerine ilgi göstermesine neden olmuştu. ${ }^{85}$ Gelinen süreç itibarıyla XIX. yüzyıldan itibaren Osmanlı topraklarında

bilgi için bkz. Uluskan, agm., s. 82. Diğer taraftan afyondan elde edilen macunlar sadece İstanbul'da değil, Afyonkarahisar gibi afyon üretimi yapılan kentlerde de bir gelir kaynağıydı. Suraiya Faroqhi, Osmanlı Kültürü ve Gündelik Yaşam (Ortaçağdan Yirminci Yüzyıla), Tarih Vakfi Yurt Yay., İstanbul 2005, s. 237-238.

${ }^{82}$ BOA, C.ML, nr. 665/27219, 24/RA/1197 (29/03/1783); BOA, C.ML, nr. 540/22213, 18/N/1207 (29/04/1793).

83 “... Zamân-ı karîbde şekerciler içinde İmâm Mehmed ve cerrâh Hasan ve Dar Sokak'da câmi' karşısında Emir Süleyman ve Rüstem Paşa câmi'i karşısında berber ve kantarcılarda el Hâc Mehmed ve Ma'cûncu çarşısında yeniçeri Mustafa ve Dîvânyolu'nda Abdullah ve Mahmud Paşa kapısı ayağında cem'an sekiz mahalle berş dükkânları ihdâs olunub dekâkîn-i mezbûre ashâbı tabh eyledikleri berş eczâsını gereği gibi bilmeyip ve keyfiyyet-i tabhda adem-i hazâkatleri müte'ayyin olduğundan mâ'adâ ba'zıları hamr ve arak ile tahmîr ve ba'zıları esrâr ve benc suyu ile ısladıb ve adem-i mahâretlerinden nice eczâsını ifrât yâhud tenkîs etmeleriyle, mübtelâsı olan nice ibâdullâhı ızrâr ve dimâğını ifsâd ve nice şenâ'ate sebeb olub... sen ki Mevlânâ-yı mûmâ ileyh Mehmed Ebû Saidzîdet fezâiluhûsun- i'lam eylediğin ecilden, i'lamın mûcebince amel ve hareket ve fîmâ ba'd i'lâma mugayir hareket edenler ahz u te'dîb ve nefy ü iclâ olunub bir türlü ruhsat verilmemek ve vakit tecessüs ve tefahhus ve bu nizâm düstûrü'l amel olunmak bâbında fermân-ı âlî-şânım sâdır olmuşdur... ”' İstanbul Kadı Sicilleri, İstanbul Mahkemesi 24 Numaralı Sicil, Belge No: 11b-1, C. 21, s. 96, 1138 (1726).

84 “'Berş i'lâmı bâ mühr-i hazret-i Efendi Ma'rûz-ı dâ '̂̀-i devletleridir ki sâhib-i arzuhâl Ahmed'in Aksaray'da Murad Paşa-yı Atîk mahallesinde vâki' dükkânında berş tabh olunan dekâkînden olmak üzre sâdır olan fermân-ı âlîlerine imtisâlen mukaddemâ mühürlenip lâkin mezbûr ba'de'l-yevm berş ve sâir mükeyyifâta müte'allik ma'âcîn tabh ve te'âtî etmeyip ancak eşribe gülşeker tabh ve te'âtî edip ol vechile sâdır olan fermân-ı âlî mûcebince hırfet-i âharl eylemek üzre ahâlî-i mahalle-i mezbûreden... Ahmed dükkân-ı mezbûr feth olunmak bâbında fermân-ı âlîlerini recâ eylediği bi 'l-iltimâs huzûr-ı âlîlerine i'lâm olundu." İstanbul Kadı Sicilleri, İstanbul Mahkemesi 24 Numaralı Sicil, Belge nr. 20a-1, C. 21, s. 129, 07/ZA/1138 (7 Temmuz 1726); BOA, C.ML, nr. 540/22213, 18/N/1207 (29/04/1793).

${ }^{85}$ Burak Çıtır, "Uluslararası Afyon Anlaşmalarında Osmanlı İmparatorluğu”, Sosyal ve Kültürel Araştırmalar Dergisi, C. I, S.1, 2015, s. 25-26; Burak Çıtır, Osmanlı'dan Cumhuriyet'e Türkiye'de Afyon Ziraati ve Ticareti (1900-1939), Yayımlanmamış YLT, Sakarya Ü. SBE, Sakarya 2015, 34. Osmanlı coğrafyasında İzmir, İstanbul, Mısır olmak üzere başlıca üç nevi afyon vardır. İzmir afyonu saf ve morfin oranı yüzde 12-14 kadar yüksek olduğundan makbuldür. İstanbul afyonunda morfin oranı yüzde 7-8 kadardır. Misır afyonu ise koyu sincabi olup morfin oranı yüzde 3-6 civarındadır. Ayrıntılı bilgi için bkz. Asuman Baytop, Türkiye'de Botanik Tarihi Araştırmaları, Tübitak Yay., Ankara 2004, s. 297. 
haşhaştan elde edilen afyonun giderek dış ticaretin en önemli ürünlerinden birisi hâline gelmesiyle birlikte, devletin ilgi alanının afyonun gelir boyutu üzerine yoğunlaştığ görülmekteydi. ${ }^{86} \mathrm{Bu}$ süreçte hâl böyle olsa da yetkili organların keyif amacıyla kullanıma yönelik mücadeleyi de bırakmadıkları anlaşılmaktadır. Nitekim yeni üretilen bazı haplarda afyon katkısı olduğunun ve bunun da tiryakilik yaptığının tespit edilmesi üzerine ilgili hapların alınıp satılmasının derhâl yasaklanması hakkındaki "Meclis-i Vâlâ" kararı, bu duruma örnek teşkil etmektedir. ${ }^{87}$

Osmanlı Devleti'nde XIX. yüzy1ldan itibaren afyon kadar uluslararası ticarete konu olmasa da özellikle yurt içi piyasada ticarete konu olan uyuşturucu maddelerin hammadde kaynaklarından birisini de kenevirden elde edilen esrar oluşturuyordu. Özellikle kenevirin ekimi, ekilen kenevirden esrar edilmesi ve elde edilen ürünün satılması ve satılan ürünlerin tüketimi de devlet tarafindan kontrol edilmeye çalışılmaktaydı. ${ }^{88}$

Esrarın keyif amacıyla kullanımına karşı daha önceki yüzyıllarda benimsenen alış ve satış hakkını "benglikçi" esnafına veren ve onların satışlarını kontrol etmeyi bir politika olarak benimseyen devlet yönetimi, bu politikayı XIX. yüzyılda da devam ettirmeye çalışmıştı. Ancak XIX. yüzyılda ekonominin geleneksel yapısının değişmeye başlaması ve dışa açılmasıyla birlikte bu maddenin ticaretini sadece bir esnaf grubuna vermekle ve onların satışlarını denetlemekle bu politikanın tam anlamıyla başarıya ulaştığını söylemek güçtür. Çeşitli arşiv kayıtlarında da zaten bu madde ticaretinin yetkisiz kişilerin veya kaçakçıların eline geçtiği, ürünlerin yurt içi ve yurt dışına rahatlıkla pazarlanabildiği belirtilmektedir. Devlet ise bu sorunun önüne geçebilmek için XIX. yüzyılın ortasında esrar ekimi ile kullanımını yasak kapsamına almaya çalışmış, bu yasağı bir müddet katı şekilde uygulamıştı. ${ }^{89}$

XIX. yüzyılın ikinci yarısında esrar üretiminin kontrol altına alınmasını öngören düzenlemeler yanında, esrarın keyif amacıyla kullanımını önlemeye yönelik mücadele çalışmaları yoğun şekilde devam etmişti. Bu bağlamda yeni bir nizamname olarak 25 Nisan 1864 tarihli "Attarlar ve Kökçüler Nizamnâmesi” yürürlüğe girmiş ve nizamname gereği artık, aktar esnafının esrar ve müstahzarlarını satması yasaklanmıştı. ${ }^{90}$ Yine bu dönemde maddenin temin edildiği ve içildiği yerler olarak düşünülen kahvehaneler ve aktar dükkânları üzerinde denetimler artmıştı. Yapılan denetimler sonucu kahvehane ve aktar dükkânlarında gizli

\footnotetext{
${ }^{86}$ Berridge, age., s. 292-293; BOA, C.ML, nr. 98/4360, 03/Receb (B)/1245 (29/12/1829); BOA, Hatt-ı Hümâyun (HAT), nr. 659/32171, 24/B/1247 (29/12/1831); BOA, Cevdet Iktisat (C.IKTS), nr. 29/1408, 12/B/1243 (29/01/1828); BOA, C.ML, nr. 331/13581, 04/B/1247 (09/12/1831); BOA, C.ML, nr. 665/27218, 23/M/1253 (29/04/1837).

${ }^{87}$ Çocuklar için yapılan haplarda afyon olduğu ihbar edildiğinden bahisle, hadisenin önlenmesi hususunda Meclis-i Vâlâ tarafından İhtisap Nazırına tahrirat yazılarak gereğinin yapılması istenmişti. Nitekim II. Mahmut tarafından kurulan ve devletin çıkardığı kanun ve nizamnamelerin uygulanıp uygulanmadığını denetleyen yüksek yasama ve yargı organı işlevi gören Meclis-i Vâlâ'nın devlet için bir gelir kaynağı olan afyonun keyif verici biçimde kullanılmasını önlemeye yönelik bu kararı, Tanzimat Dönemi’nde devletin bakış açısını yansıtması açısından önemliydi. Ayrıntılı bilgi için bkz. BOA, Sadaret Mektubî Kalemi Meclis-i Vâlâ (A.MKT.MVL), nr. 2/15, 16/C/1261 (22/06/1845). Osmanlı Devleti'nde Meclis-i Vâlâ'nın görevleri hakkında bkz. Ali Akyıldız, "Meclis-i Vâlâ Ahkâm-1 Adliyye", İslam Ansiklopedisi, C. 28, TDV Yay., Ankara 2003, s. 250-251.

${ }^{88}$ BOA, Şûrây-ı Devlet (Ş.D), nr. 290/44, 01/RA/1299 (21/01/1882); BOA, Z.B, nr. 601/130, 15/Şevval (L)/1324 (02/12/1906).

89 Devletin esrar yasağını katı bir şekilde uygulama motivasyonunun arkasında, esrarın ahlaki ve davranış problemlerine yol açması ve bunun da toplumsal yaşam içerisinde rahatlıkla görülebilmesinin etkisi söz konusudur. Dolayısıyla devletin iktisadi açıdan alış ve satış üzerindeki yasaklayıcı tavrında toplumsal hassasiyetlerin de rolünün bulunduğu anlaşılmaktadır. Nitekim XIX. yüzyıldan itibaren arşiv belgelerinden elde edilen bilgilere göre uyuşturucuyla mücadelenin asıl yönünü esrar teşkil etmektedir. Buna karşı afyon ise ilaç sanayiinin aradığı bir ürün olarak yurt dışına gönderilen önemli bir ihraç kalemidir. Esrar üzerindeki kontroller ve yasaklar hakkında bkz. BOA, İrade Dâhiliye (İ.DH), nr. 229/13732, 23/Cemaziye'l-ahir (C)/1267 (25/04/1851); BOA, MVL, nr.179/59, 21/N/1273 (15/05/1857).

90 Turhan Baytop, “Esrar”, s. 432.
} 
bölümlerde esrar imal ettiği, satış yaptığı veya içilmesine ortam sağladığı tespit edilen dükkânlarının kapatılması ise sık karşılaşılan bir uygulama olarak dikkat çekmişti. ${ }^{91}$

Esrarın üretim, satış ve tüketimini önlemeye yönelik uygulamalar, 1885 civarına kadar devam etmiş ancak 1886 yılında yeni bir karar alınarak yasak, daha esnek hâle getirilmişti. Alınan karar doğrultusunda esrar ekimi yasağı kaldırılmış, bunun yerine izinsiz şekilde satanların ve keyif amacıyla kullananların cezalandırılması benimsenmişti. ${ }^{92}$ Dolayısıyla bu süreçte esrarla mücadelenin odak noktasını keyif amacıyla kullanım oluşturmuştu.

Osmanlı Devleti'nde XIX. yüzyılın ikinci yarısından itibaren çıkarılan nizamnamelerle esrarın keyif amacıyla kullanılmasını önleme çalışmalarında devletin temel politikasının, arzın kontrol altına alınması olduğu anlaşılmaktadır. Nitekim bu süreçte bir taraftan kahvehane ve aktar dükkânları üzerinde denetimler sıkı bir şekilde devam ederken diğer taraftan da kahvehane ve aktar dükkânlarına mal getiren veya kayıt dışı olarak esrar alanlar üzerinde denetimler yapılmaktaydı. Yapılan denetimlerde ve gümrük kontrollerinde edinilen bazı bilgilere göre uyuşturucu madde temin edilmesine olanak sağlayan kaynaklardan birisinin de yabancılar olduğu dikkati çekmekteydi. ${ }^{93}$ Devlet de bu durum karşısında gerek Osmanlı tebaası içindeki gayrimüslimler gerekse de sefaretlerdeki yabancıların bu işlere tevessül etmemeleri için yasal sınırlar çerçevesinde mücadele etmekte ve bunun yanı sıra ilgili ülkelerin sefaretleri ile yakın çalışmaya girmekteydi. ${ }^{94}$

Osmanlı Devleti'nin uyuşturucu maddelerle iktisadi alandaki mücadelesi, XIX. yüzyılda hâkim olan görüşler temelinde XX. yüzyılda da devam etmişti. Bu noktada keyif amacıyla kullanım, yasak kapsamında değerlendirilirken, arz merkezi olarak görülen mekânlar ve işletmeler üzerindeki denetimlerin aynı şekilde kararlılıkla sürdürüldüğü görülmekteydi. ${ }^{95}$ Isşte bütün bu girişimler, Osmanlı devlet yönetiminin esrar başta olmak üzere uyuş̧turucu maddelerle mücadelesi açısından önemli olarak kabul edilmelidir. Nihayetinde esrarın kötüye

\footnotetext{
${ }^{91}$ Kahvelerinde esrar üreten ve satan Berber Mehmet ve Mustafa ile müşterileri hakkında cezai işlem yapılması hakkında bkz. BOA, Sadaret Mektubî Kalemi Nezâret ve Devâir (A.MKT.NZD), nr. 77/17, 05/L/1269 (12/07/1853). Esrar maddesinden dolayı dükkânı kapatılan Hacı Mustafa, Mehmed Ali Çavuş ve Hacı Süleyman'ın arzuhâli hakkında bkz. BOA, MVL, nr. 180/79, 13/L/1273 (06/06/1857). Bazı kahvehanelerde gonca ve esrar imal edildiği ve bunun men edilmesine dair bkz. BOA, Iradeler Meclis-i Vâla (İ.MVL), nr. 305/21, 01/L/1273 (25/05/1857); BOA, I. $M V L, \mathrm{nr}, 495 / 22414,16 / \mathrm{Z} / 1280(23 / 05 / 1864)$.

92 BOA, Sadaret Mühimme Kalemi Evrakı (A.MKT,MHM), nr. 489/10, 20/N/1303 (22/06/1886); BOA, Şûray-ı Devlet (SSD), nr. 1180/3, 01/Şaban (Ş)/1303 (05/05/1886); BOA, ŞD, nr. 1577/16, 18/RA/1319 (05/07/1901). Karamürsel'in Cedid köyünde izinsiz olarak ekilen esrarların sökülmesi ve bu tür zirai faaliyetlerin men edilmesi hakkında BOA, DH.MKT, nr. 2245/80, 01/M/1317 (06/05/1899).

93 Suriye'ye gitmek üzere Selânik'ten hareket eden Fransızlara ait Messagerie vapurunda büyük miktarda esrar bulunması üzerine gemide diğer mallara da el konulmuş ve Akdeniz'e komşu diğer vilayetlerin yetkililerinden, özellikle bu tür ticari faaliyetlerde bulunan yabancılara ait malları yakından takip etmeleri istenmişti. BOA, Bâb- $l$ Âlî Evrak Odası (BEO), nr. 475/35608, 18/N/1312 (15/03/1895). 1885 Y1lında gümrüklerde yapılan bir denetimde İzmirli tüccar Serope Agobyan'a ait seksen yedi kıyye esrar ele geçirilmişti. BOA, ŞD, nr. 1178/13, 08/L/1302 (21/07/1885); BOA, Sadaret Hususi Maruzâtı (Y.A.HUS), nr. 308/129, 16/N/1312 (13/03/1895). Esnafa silah ve cephane sattığ yolunda haberler alınan ve Adana'daki ikametgahında yapılan aramada Nersis veled-i Agob ile babasında beş kıyye esrar bulunmuş ve bunun üzerine ilgili kişiler hakkında adli ve idari işlemler başlatılmıştı. BOA, Dâhiliye Nezareti Şifre Kalemi (DH.ŞFR), nr. 238/104, 19/Z/1315 (11/05/1898). Esrar ve müskirat sattıklarından dolayı kapatılan Galata'daki İranlıların bulunduğu kahvehanelerin yasak madde satılmamak şartıyla açılmasına müsaade edilmişti. BOA, ZB, nr. 389/165, 09/L/1322 (17/12/1904).

${ }^{94}$ Yunan konsolos vekilinin kendine ait dükkânında müskirat ve esrar satıldığının tespiti üzerine Osmanlı Devleti tarafından konsolos vekilliği görevinin artık tanınmadığı, bunun yerine yeni bir görevlinin tayin edilmesi talep edilmiş ve daha sonra yeni bir konsolos vekili görevlendirilmişti. BOA, Hariciye Nezareti Tahrirât Kalemi (HR.TH), nr. 118/85, 07/L/1309 (05/05/1892).

95 Esrar sattığı ihbar edilen kahvehanelere yapılan denetimler sonucu bu işi yaptığı tespit edilen dükkânlar derhâl kapatılmıştı bkz. BOA, ZB, nr. 347/134, 22/R/1323 (26/06/1905). Eczanelerde fazla miktarda esrar bulundurulmasının satış ve kullanıma imkân verebileceği endişesinden dolayı bu işin yakından takip edilmesi hakkında BOA, Tahrirat Kalemi Emniyet-i Umumiye ((DH.EUM.THR), nr. 53/65, 23/L/1328 (28/10/1910). Nizamname gereği afyondan yapılan tiryak müstahzaratının, aktar ve saire tarafından satılmasının yasak olduğu ve bu yasağın titizlikle uygulanması istenmişti. BOA, ZB, nr. 596/93, 06/Safer (S)/1323 (12/04/1905).
} 
kullanılmasını ve kaçak yollardan temin edilmesini önlemeye yönelik iktisadi mücadele çalışmaları, Osmanlı Devleti'nin son zamanlarına kadar devam etmiştir.

\subsection{Sağlık Alanında Mücadele Çalışmaları}

Uyuşturucu maddeye kaynaklık eden bitkilerden haşhaştan elde edilen afyon ile kenevirden elde edilen esrar, ağrı kesici ve tedavi edici özellikleri nedeniyle eski uygarlıklardan itibaren sağlık sektörünün aranan ürünleri arasında yer almıştır. Aynı şekilde Osmanlı Devleti'nin kuruluşundan itibaren afyon, esrar ve bunlardan elde edilen karışımlar, öncelikli olarak tıbbi gayelerle müracaat edilen ürünler olarak dikkati çekmiştir.

Osmanlılarda uyuşturucu özelliği bulunan maddelerin öncelikli olarak sağlık alanında kullanılması teşvik edilmekteydi. Ancak geleneksel usullerle imal edilen afyon, afyon macunları ve şurupları ile esrar türevi ürünler, zengin uyuşturucu içeriği nedeniyle tiryakiler tarafından keyif verici bir madde olarak da kullanılmaktayd $1 .{ }^{96}$ Maddelerin amacı dışında kullanılması ise devleti ve toplumu yakından ilgilendiren bir sağlik meselesiydi ve devlet tarafından da bu durum bir sorun olarak algılandığı için devletin sağlık alanındaki mücadelesi yüzyıllarca devam etmişti. $\mathrm{Bu}$ süreçte sağlık gerekçesi dışında uyuşturucu kullanımıyla mücadele edilmesi gerektiği şeklinde devlette hâkim olan bakış açısına özellikle Klasik Dönemde aydınlar ve ilim adamlarından da destek gelmişti. Nitekim XVII. yüzyılın büyük düşünürü Kâtip Çelebi; afyon, afyon şurubu ve buna benzer maddelerin ilaç kabilinden olduğunu ve bunların sadece tedavi amacıyla kullanılması gerektiğinin altını çizmek suretiyle keyif amaciyla kullanımdan uzak durulmasını öğütlemekteydi. ${ }^{97}$ Yine Osmanlı toplumunda afyon ve esrarın gerçek amacı doğrultusunda kullanılmasını sağlamaya yönelik politikalar, XVII. yüzyılda olduğu gibi XVIII. yüzyılda da devam etmişti. Bu doğrultuda afyon ve esrarın sadece geleneksel tıp alanında kullanılması gerektiğine dikkat çekilmiş, tedavi amacı dışındaki kullanım, padişahlar başta olmak üzere devlet yetkililerini meşgul eden önemli meseleler içinde yer almıştı. ${ }^{98}$

Tarihsel süreç içerisinde uyuşturucu maddelerin ön plana çıkmasında dikkati çeken bir dönem de XIX. yüzyıldır. Bu dönemde ilaç sanayiindeki gelişmelerle birlikte Avrupa'da morfin ve eroin gibi yeni maddelerin keşfedilmesi, uyuşturucu özelliği taşıyan maddelere sağlık alanında yeni bir boyut kazandırmıştır. ${ }^{99}$ XIX. yüzyılda Avrupa'da yaşanan bu tür gelişmelerle birlikte artık Osmanlı Devleti'nde de afyon ve esrar, ilaç sanayiinin bir ürünü olarak varlık göstermiştir. Böylece zehirlenme vakalarının tedavisinde, deri altı enjeksiyonlu işlemlerde ve ameliyat gibi ileri düzeyli tıbbi operasyonlarda afyon ve esrar ekstresinden hazırlanan macunlar ile afyon türevi morfin ve eroin maddesi yoğun şekilde sağlık alanında kullanılmıştır. ${ }^{100}$ Uyuşturucu içeriğe sahip yeni ürünlerin tıbbi yararlarına rağmen geleneksel uyuşturuculardan daha fazla bağımlılık yapması, dünya genelinde bu maddelerle tıbbi çerçevede mücadele politikalarının hayata geçmesini sağlamıştır. ${ }^{101}$

Dünyada olduğu gibi Osmanlı Devleti'nde XIX. yüzyılda ilaç sanayiinde yaşanan hızlı değişimler, geleneksel usuller çerçevesinde aktarlar esnafina bağlı faaliyet yürüten, afyoncu ve

\footnotetext{
${ }^{96}$ Evliyâ Çelebi Seyahatnâmesi II. Kitap, s. 607-608; Turhan Baytop, "Eczacılık”, s. 387.

${ }^{97}$ Batılı seyyahlar ve diplomatlar, Osmanlı başkentinde bürokratlar ve yüksek tabakaya mensup kişiler tarafından XVII. yüzyılda afyon ve esrar kullanımının yaygın olduğunu, özellikle Padişahın daha katı tedbirler almasında bu durumun da etkisinden bahsedilmektedir. Mossensohn, age., s. 42-43; Kâtip Çelebi, Mîzân'ül-Hakk Fî İhtiyâr'ilAhakk, s. 50.

${ }_{98}$ BOA, C.ZB., nr. 73/3613, 19/ZA/1179 (29/04/1766); BOA, C.ML, nr. 540/22213, 18/N/1207 (29/04/1793).

${ }^{99}$ Schivelbusch, age., s. 211; Booth, age., s. 60; Foxcroft, , age., s. 10; Seddon, agm., s. 143-144.

${ }^{100}$ Osmanlılarda 1868 yılında göz iltihabı olan bir hastayı tedavi etmek için normal dozda gümüş nitrat ve atropin sülfat çözeltisi verilmiş ve aniden zehirlenme belirtileri (şiddetli susama ve kusma) gözlenmiştir. Daha sonra hasta, "derin komaya" girmiş ve iki kez morfin enjeksiyonu verilmek suretiyle ancak 90 saat sonra komadan çıkabilmiştir. Yine 1871 yılında görülen bir vakada dalgınlıkla atropin sülfat içmek suretiyle zehirlenme belirtileri gösteren bir kişi, afyon tentürü ve iki kez deri altı morfin enjeksiyonu uygulaması suretiyle tedavi edilmişti. Eyüp Talha Kocac1k ve Afife Mat, agm., s. 30-31.

${ }^{101}$ Babaoğlu, age., s. 54-55; Seddon, agm., s. 143-144.
} 
esrarcı esnafı doğrudan etkilemiştir. Özellikle Kırım Savaşı (1854) ve sonrasındaki gelişmelerle İstanbul'a Fransız ve İngiliz askerî hekim ve eczacıların gelmesiyle, İstanbul'da da modern anlamda eczaneler açılmaya başlamıştır. ${ }^{102} \mathrm{Bu}$ süreçte bir taraftan afyon ve esrarın keyif amacıyla kullanımının artması bir taraftan da afyon ve esrarın bağımlılık yapıcı etkilerinin farkına varılması ve bunun sonucundaki uluslararası gelişmeler, Osmanlı Devleti'nde afyon ve esrarın bağımlılık ekseninde değerlendirilmesine yol açmıştır. ${ }^{103}$ Gelinen süreçle birlikte esrar, afyon ve bunlardan üretilen sentetik maddelerin sağlık alanı dışında kullanılmasını engellemek için mücadeleler başlamış ve bu doğrultuda Osmanlı Devleti tarafindan yeni bir nizamname yayımlanmıştır. 1864 tarihli "Attarlar ve Kökçüler Nizamnâmesi” uyarınca artık aktar esnafının esrar ve müstahzarlarını satması yasaklanmış, yalnız eczanelerin doktor reçetesi karşılığı satış yapmalarına izin verilerek modern sağllk sistemini ve bunun gereklerini yerine getirmeye yönelik yeni bir evreye geçilmiştir. ${ }^{104}$ Afyon ve esrarın sadece tıbbi amaçlar doğrultusunda kullanılmasını öngören bu düzenleme, önemli bir kesintiye uğramadan XX. yüzyılın başlarında da varlığını sürdürmüştür. ${ }^{105}$

Osmanlı Devleti'nde ilaç sanayii ve eczacılık alanında meydana gelen bu yeni süreç, afyon ve esrarın modern tıbbın kapsamı içerinde değerlendirilmesini ve ayrıca geleneksel olarak imal edilen esrar ve afyon mamulü ürünler ile ilaçlar üzerinde devletin tıbbi denetimlerinin artmasını sağlamıştır. Bu kapsamda özellikle ilaçların doktor reçetesi ile de olsa kullanılıp kullanılmaması hususunda sağlık kuruluşlarının görüşü önem kazanmıştır. ${ }^{106}$ Nihayetinde XIX. ve XX. yüzyılda Osmanlı Devleti'nde uyuşturucu maddelerin sadece tıbbi amaçlarla kullanılmasını sağlamaya ve bu maddelerin keyif amacıyla kullanımını önlemeye yönelik mücadele çalışmalarına rağmen madde kullanım sorunu, belli ölçülerde varlığını devam ettirmiştir.

\section{Sonuç}

Osmanlılarda esrar ve afyon, ağrı kesici ve tedavi edici özellikleri nedeniyle sağlık sektörünün aranan ürünleri arasında kendine yer edinmiştir. Bu ürünler, sağlik sektöründe talep görmüş olmasına rağmen uyuşturucu içeriği nedeniyle keyif verici maddeler olarak da en sık kullanılan uyuşturucular kategorisinde sıralanmış ve afyon, afyondan elde edile macunlar (berş) ile esrar, toplumun geneline yansımasa da bir kullanım alanına sahip olmuştur.

Osmanlı toplumunda uyuşturucu özelliği bulunan maddeler, esnaflık nizamına göre aktarlar grubuna bağlı faaliyet yürüten esnaf zümresi tarafindan piyasada arz edilmeye çalışılmıştır. İlgili esnaf zümresine satış hakkı tanınmasında ise halkın sağlık ve şifa ürünlerine ihtiyacı belirleyici rol oynamıştır. Bundan dolayı ilgili esnafların sadece sağlık ürünü şeklinde piyasada satış yapmalarına müsaade edilmiştir. Ancak bu yöndeki düzenlemelere rağmen bir

\footnotetext{
1021868 yılında İstanbul'da elli, Üsküdar'da on kadar eczane olduğu ve bunların Osmanlı vatandaşı veya yabanc1 uyruklu gayrimüslimlerce işletildiği bilinmektedir. Müslümanlar ancak 1880'li yıllardan itibaren eczane açmaya başlamışlardır. 1900 yıllarında İstanbul'daki eczane sayısı 200 civarındadır ve bunlardan yalnız on tanesinin sahibi Türk’tür. Ayrıntılı bilgi için bkz. Turhan Baytop, "Eczacılık”, s. 387.

${ }^{103}$ Kilıç, agm., s. 163.

104 Turhan Baytop, “Esrar”, s. 432.

105 Nizamname gereği ancak doktor reçetesi ile verilebilecek olan ve afyondan yapılan tiryak müstahzaratının, eczanelerde reçete ile satılabileceği ve bunun dışında aktar ve saire tarafından satılmasının yasaklanmasına devam edilmesi hakkında bkz. BOA, ZB, nr. 596/93, 06/S/1323 (12/04/1905); BOA, DH.MKT, nr, 2851/20, 13/CA/1327 (02/06/1909); BOA, DH.MKT, nr. 2910/51, 21/B/1327 (08/08/1909).

${ }^{106}$ Osmanlı Devleti'nin son dönemlerine doğru "Mekteb-i Tıbbiye-i Şahane" ile "Tıbbiye-i Mülkiye ve Sıhhiye-i Umûmiye" gibi tıbbi alanda yetkili birimler, kullanılan ilaçların piyasadan toplanmasına karar verebildiği gibi bağımlılık özelliği bulunan bazı ilaçların tıbbi bir zorunluluktan dolayı ithal edilmesi yönünde tavsiye kararlarına da varabiliyordu. Nitekim 1892 yılında Sulfanol ve Kokain adlı ilaçların bütün vilayetlerde yasaklanması yönündeki karar ile afyon, morfin ve benzeri uyuşturucuların tıbbi maksatlarla ithallerine verilen nihai devlet kararlarında, sağlık alanında yetkili kurumların görüş ve tavsiyeleri etkili olmuştu. Ayrıntılı bilgi için bkz. BOA. DH.MKT, nr. 1902/50, 16/L/1309 (14/05/1892); BOA, Meclis-i Vükela (M.V), nr, 223/113, 10/Z/1340 (04/08/1922).
} 
kısım esnafin uyuşturucu tiryakilerine mal satışı yaptığı görüldüğünden, bu nizama tam anlamiyla riayet edilmediği için devlet otoritesinin soruna müdahil olduğu ve arz merkezleri olarak bilinen esnaflar üzerinden piyasayı denetlediği çeşitli arşiv belgelerinden görülmüştür.

Osmanlılarda keyif amacıyla uyuşturucu madde kullanım meselesinde dikkati çeken hususlardan birisi de esnaflar üzerinden mal temin eden tiryakilerin uyuşturucu maddeyi aleni biçimde kullanmadığıdır. Nitekim tiryakilerin çoğunlukla kahvehanelerde gizli bir şekilde kullandıkları ve kullanıcı olduklarının anlaşılması üzerine de toplumsal ve ekonomik itibarlarını önemli ölçüde kaybettikleri anlaşılmıştır. Dolayısıyla Osmanlı toplumunda uyuşturucu madde tiryakilerine toplum tarafından da olumlu bir gözle bakılmadığ 1 için özellikle Osmanlı Klasik Dönemi'nde devlet ve toplum hayatında tesirleri olan şair, düşünür ve ulema tarafından afyon ve esrarı keyif amacıyla kullananların içine düştükleri ibretlik hâller tasvir edilerek topluma nasihatlerde bulunulmuştur. $\mathrm{Bu}$ doğrultuda şair, düşünür ve ulema tarafından madde kullanımının dinî, ahlaki, fiziksel ve ruhsal açılardan sıkıntılara sebebiyet vereceği vurgulanmak suretiyle madde kullanımıyla topyekûn mücadele edilmesi tavsiye edilmiştir.

Osmanlılarda uyuşturucu madde kullanımı, toplum tarafindan sakıncalı görülmekle birlikte aynı şekilde kamu otoritesinin de bakış açısı, devlet olarak sorunla mücadele etmek şeklindedir. Nitekim devletin adalet, idare, iktisat ve sağlık boyutlarıyla çeşitli mücadele faaliyetleri yürüttüğü ve bazı durumlarda ciddi yaptırımlara başvurduğu dikkati çekmiştir. Duruma örnek teşkil etmesi açısından, bağımlılık yapıcı maddeleri kullananların bunu diğer kişilere de sirayet ettirme ihtimali değerlendirilerek devlet otoritesinin hukuki noktada ta'zîr cezaları başta olmak üzere, sosyal çevreden uzaklaştırmayı ihtiva eden sürgün edilme gibi toplumsal ve hukuki sonuçlar doğuran yaptırımlar uyguladıkları görülmüştür. Yine bunun yanı sıra keyif amacıyla uyuşturucu madde sattığı tespit edilen esnafların dükkânlarının kapatılması, mallarına el konulması, doktor reçetesi dışında satılmaması ve kullanılmaması, devletin farklı alanlarda ve boyutlarda mücadele çalışmalarını göstermiştir.

Osmanlı Klasik Dönemi'nden itibaren geçerli olmak üzere Osmanlı Devleti'nin son zamanlarına kadar keyif amacıyla uyuşturucu madde kullanımına karşı devletin mücadele politikaları birçok alanda kendini gösterirken, Amerika ve Avrupa gibi gelişmiş ülkelerde bu politikalar ancak XIX. yüzyılın son dönemlerinden itibaren hayata geçmeye başlamıştır. Bunda ise şüphesiz ilaç sanayiindeki gelişmelerle birlikte morfin, kodein ve eroin gibi maddelerde seri üretime geçilmesi ve bu ürünlerin tıbbi amaç dışında keyif verici biçimde yaygın şekilde kullanılmasının rolü bulunmaktadır. Hâlbuki Avrupa ülkelerinde uyuşturucu madde kullanımı sadece XIX. yüzyılın son dönemlerinde değil, yüzyıllarca öncesine dayanmaktadır. Avrupa ülkeleri ve Amerika'nın harekete geçmesinde ise yeni uyuşturucu maddelerin Batı toplumlarında hızlı biçimde yayılmasının etkisi söz konusudur. Dolayısıyla ancak XIX. yüzyılın sonlarından itibaren Avrupa ülkeleri ve Amerika'da madde kullanımı halk sağlığı problemi olarak görülmeye başlamıştır. Bunun sonucunda da dünya genelinde üretimin yasaklanması da dâhil olmak üzere katı mücadele politikaları kendini hissettirmiş ve önemli bir afyon üreticisi olan Osmanlı Devleti de bundan ekonomik olarak olumsuz şekilde etkilenmiştir.

\section{Kaynakça}

\section{Osmanlı Arşivi Kaynakları}

BOA, Bâb-ı Âlî Evrak Odası (BEO), Dosya No: 475, Gömlek No: 35608 (nr. 475/35608).

BOA, Cevdet İktisat (C.IKTS), nr. 29/1408.

BOA, Cevdet Maliye (C.ML), nr. 98/4360, 331/13581, 450/18215, 540/22213, 665/27218, $665 / 27219$.

BOA, Cevdet Zabtiye (C.ZB.), nr. 73/3613. 
BOA, Dâhiliye Emniyet-i Umumiye Emniyet Şubesi Evrakı (DH.EUM.EMN), nr. 113744.

BOA, Dâhiliye Nezareti Emniyet-i Umumiye Tahrirat Kalemi (DH.EUM.THR.), nr. 22/19-0, $53 / 65$.

BOA, Dâhiliye Nezareti İdare Evrakı (DH.ID), nr. 87/30.

BOA, Dâhiliye Nezareti Mebâni-i Emiriye Hapishaneler Müdüriyeti (DH.MB.HPS), nr.165/76.

BOA, Dâhiliye Nezareti Mebâni-i Emiriye Hapishaneler Müdüriyeti Müteferrik Evrakı (DH.MB.HPS.M), nr. 46/17.

BOA, Dâhiliye Nezareti Mektubî Kalemi (DH.MKT), nr. 780/50, 946/6, 1902/50, 2245/80, 2370/7, 2851/20, 2836/30, 2910/51.

BOA, Dâhiliye Nezareti Şifre Kalemi (DH.ŞFR), nr. 342/81, 414/85, 238/104.

BOA, Dâhiliye Nezareti Tesri-i Muamelât ve Islahat Komisyonu (DH.TMIK.M), nr. 168/9.

BOA, Divan-ı Hümâyun Mühimme Defteri (A.DVNSMH.d), nr. 35/225, 35/544.

BOA, Hariciye Nezareti Hukuk Müşavirliği İstişare Odası Evrakı (HR.HMŞ.IŞSO), nr. 186/71.

BOA, Hariciye Nezareti Tahrirât Kalemi (HR.TH), nr. 118/85.

BOA, Hatt-ı Hümâyun (HAT), nr. 659/32171.

BOA, Hazine-i Hâssa Nezareti Defterleri (HH.d), nr. 24838.

BOA, Irade Dâhiliye (I.DH), nr. 229/13732.

BOA, Iradeler Meclis-i Vâla (İ.MVL), nr. 305/21, 495/22414.

BOA, Maliyeden Müdevver Defter (MAD.d), nr. 9674, 8312.

BOA, Meclis-i Vâlâ Riyâseti (MVL), nr. 179/53,179/59, 180/79.

BOA, Meclis-i Vükela (M.V), nr, 223/113.

BOA, Sadaret Hususi Maruzâtı (Y.A.HUS), nr. 308/129.

BOA, Sadaret Mektubî Kalemi (A.MKT), nr. 28/57.

BOA, Sadaret Mektubî Kalemi Meclis-i Vâlâ (A.MKT.MVL), nr. 2/15.

BOA, Sadaret Mühimme Kalemi Evrakı (MKT.MHM), nr. 489/10.

BOA, Sadaret Nezaret ve Devair Evrakı (MKT.NZD), nr. 77/17.

BOA, Şûrây-ı Devlet (Ş.D), nr. 290/44, 1577/16, 1178/13, 1180/3.

BOA, Zabtiye Nezareti (ZB), nr. 308/50, 347/134, 389/165, 490/88, 596/93, 601/130.

\section{Yayınlanmış Osmanı Arşivi Kaynakları ve Kadı Sicilleri}

Başbakanlık Osmanlı Arşivleri, 7 Numaralı Mühimme Defteri (975-976/1567-1569), C. I, nr.1012, 417, Dîvân-1 Humâyûn Sicilleri Dizisi: V, Devlet Arşivleri Genel Müdürlügüu Yay., Ankara 1998.

İstanbul Kadı Sicilleri, İstanbul Mahkemesi 24 Numaralı Sicil, C. 21, TDV İSAM Yay.

\section{Basılı Eserler ve Tezler}

Abdülaziz Bey, Osmanlı Âdet, Merasim ve Tabirleri, hzl. Kâzım Arısan, Duygu Arısan Günay, Tarih Vakfi Yurt Yay., İstanbul 1995.

Ali Haydar, Haş̧aş Ziraatı, Matbaa-i Osmaniyye, Dersaadet 1330. 
Amasyan Efendi, Afyon Tohumu Ziraatı Layihası, La Türki Matbaası, İstanbul 1287.

Babaoğlu, Ali Nahit, Uyuşturucu ve Tarihi, Kaynak Yay., İstanbul 1997.

Baytop, Asuman, Türkiye'de Botanik Tarihi Araştırmalarl, Tübitak Yay., Ankara 2004.

Baytop, Turhan, Türkiye'nin Tibbi ve Zehirli Bitkileri, İstanbul Ü. Yay. , İstanbul 1963.

Berridge, Virginia, Opium and the People (Opiate Use and Drug Control Policy in Nineteenth and Early Twentieth Century England), London 1999.

Beyzâdeoğlu, Süreyya Ali, Sünbülzâde Vehbî Lutfiyye, Cihan Neşriyat ve Matbaacılık, İstanbul 1996.

Booth, Martin, Haşhaştan Eroine Uyuşturucunun 6000 Ylllı Öyküsü, Sabah Kitapları, İstanbul 1996.

Bulduk, Üçler, XVI. Asırda Karahisar-ı Sahib Sancağı, Yayımlanmamış DT, Ankara Ü. SBE, Ankara 1993.

Çıtır, Burak, Osmanlı'dan Cumhuriyet'e Türkiye'de Afyon Ziraati ve Ticareti (1900-1939), Yayımlanmamış YLT, Sakarya Ü. SBE, Sakarya 2015.

D’Ohsson, Mouradgea, 18. Yüzyll Türkiyesinde Örf ve Adetler, çev. Zehran Yüksel, Tercüman 1001 Temel Eser, Tarihsiz.

Demirbaş, Timur, Kriminoloji, 2. Baskı, Seçkin Yay., Ankara 2005.

Develioğlu, Ferit, Osmanlıca Türkçe Ansiklopedik Lûgat, Aydın Kitabevi, 30. Baskı, Ankara 2013.

Dönmezer, Sulhi, Kriminoloji, Beta Yay., 8. Bask1, İstanbul 1994.

Düzdağ, M. Ertuğrul, Şeyhülislâm Ebûssuud Efendi Fetvalarl Işığında 16. Asır Türk Hayatı, Enderun Kitabevi Yay., İstanbul 1972.

Erdinç, F. Cengiz, Overdose Türkiye, İletişim Yay., İstanbul 2004.

Evliyâ Çelebi Seyahatnâmesi (I. Kitap), hzl. Orhan Şaik Gökyay, Yapı Kredi Yay., İstanbul 1999.

Evliyâ Çelebi Seyahatnâmesi (II. Kitap), hzl. Seyit Ali Kahraman ve Yücel Dağlı, Yapı Kredi Yay., 5. Bask1, İstanbul 2008.

Evliyâ Çelebi Seyahatnâmesi (IX. Kitap), hzl. Yücel Dağlı, Seyit Ali Kahraman ve Robert Dankoff, Yapı Kredi Yay., İstanbul 2005.

Faroqhi, Suraiya, Osmanlı Kültürü ve Gündelik Yaşam (Ortaçağdan Yirminci Yüzyıla), Tarih Vakfi Yurt Yay., İstanbul 2005.

Faroqhi, Suraiya, Osmanlı'da Kentler ve Kentliler, çev. Neyyir Kalaycıŏlu, Tarih Vakfı Yurt Yay., İstanbul 2000.

Foxcroft, Louise, The Making of Addiction (The 'Use and Abuse' of Opium in NineteenthCentury Britain), Published by Ashgate, England 2007.

Gelibolulu Mustafa Âli, Mevâidü'n-Nefâis Fî Kavâidi'l Mecâlis I (Görgü ve Toplum Kuralları Üzerinde Ziyâfet Sofraları), hzl. Orhan Şaik Gökyay, İstanbul 1978.

Genç, Mehmet, Osmanlı İmparatorluğunda Devlet ve Ekonomi, 4. Baskı, Ötüken Yay., İstanbul 2005.

Karadeniz, Kibar, Bă̆ımlılık Yapan Madde Kullanma Suçlarının İslam Hukuk Sosyolojisi Açısından Değerlendirilmesi, Yayımlanmamış YLT, Ankara Ü. SBE, Ankara 2009. 
Kâtip Çelebi, Mîzan'ül-Hakk Fi İhtiyari'l-Ahakk, hzl. Orhan Şaik Gökyay, Tercüman 1001 Temel Eser, İstanbul 1980.

Köknel, Özcan, Bağımlılık (Alkol ve Madde Băğımlılı̆̆l), Altın Kitaplar Yay. İstanbul 1983.

Mossensohn, Miri Shefer, Ottoman Medicine: Healing and Medical Institutions, 1500-1700, NY Suny Press, New York Albany 2009.

Muallim Şövalye Hasan Bahri, Esrarkeşler, hzl. Süha Ünsal, Kebikeç Yay., Ankara 1997.

Nâbi, Hayriyye, hzl. Mahmut Kaplan, Kültür ve Turizm Bakanlığı Yay., Ankara 2019.

Ögel, Kültegin, Sigara, Alkol ve Madde Kullanım Bozuklukları: Tanı, Tedavi ve Önleme, Yeniden Yay., İstanbul 2010.

Öztürk, Metin, Sihhatî Çelebi'nin "Menâkıb-ı Mükeyyifât-ı Âlem" Risalesi Çerçevesinde 17. Yüzyıl İstanbul'unda Keyif Verici Maddeler, Yayımlanmamış YLT, Hacettepe Ü. SBE, Ankara 2006.

Quataert, Donald, Anadolu'da Osmanlı Reformu ve Tarımı (1876-1908), Çev. Nilay Özok Gündoğan ve Azat Zana Gündoğan, Türkiye İş Bankası Kültür Yay., İstanbul 2008.

Schivelbusch, Wolfgang, Keyif Verici Maddelerin Tarihi, çev. Zehra Aksu Y1lmazer, Genesis Kitap Yay., Ankara 2012.

Stevens, Alex, Drugs, Crime and Public Health (The Political Economy of Drug Policy), Taylor \& Francis Group, New York 2011.

\section{Süreli Yayınlar}

Ağırakça, Ahmed, “Osmanlı Tıbbının Kaynakları”, Osmanlılarda Sağlık, C. I, Health in The Ottomans, ed. Coşkun Yılmaz-Necdet Yılmaz, Biofarma Yay., İstanbul 2006. ss, 133165.

Akyıldız, Ali, "Meclis-i Vâlâ-yı Ahkâm-1 Adliyye", İslam Ansiklopedisi, C. 28, TDV Yay., Ankara 2003, ss. 250-251.

Altan, Suna, "Cenevre Afyon Konferansları ve Türkiye'nin Tutumu”, Çanakkale Araştırmaları Türk Yıllı̆̆gl, Bahar 2019, S. 26, ss. 45-70.

Baktır, Mustafa, “Afyon”, İslam Ansiklopedisi, C. 1, TDV Yay., İstanbul 1988, ss. 442-443.

Başoğlu, Tuncay, "Uyuşturucu”, İslam Ansiklopedisi, C. 42, TDV Yay., İstanbul 2012, ss. 248253.

Baytop, Turhan, "Eczacılık”, İslam Ansiklopedisi, C. 10, TDV Yay., İstanbul 1994, ss. 386-388.

Baytop, Turhan, “Esrar”, İslam Ansiklopedisi, C. 11, TDV Yay., İstanbul 1995, ss. 431-432.

Berridge, Virginia, "Two Tales of Addiction; Opium and Nicotine”, Human Psychopharmacology, Volume: 12, London 1997, pp. 45-52.

Bilgin, A. Azmi, “Lutfiyye”, İslam Ansiklopedisi, C. 27, TDV Yay., Ankara 2003, ss. 236-237.

Çolak, Filiz, "Anadolu'da Afyon Ziraati ve Ticaretine Dair İzlenimler”, The Journal of Academic Social Science Studies, V. 6/1, January 2013, ss. 513-529.

Çıtır, Burak, "Uluslararası Afyon Anlaşmalarında Osmanlı İmparatorluğu", Sosyal ve Kültürel Araştırmalar Dergisi, C. I, S.1, 2015, ss. 17-47.

Erkal, Abdulkadir, "Divan Şiirinde Afyon ve Esrar", Atatürk Ü. Türkiyat Araştırmaları Enstitüsü Dergisi, S. 33 Erzurum 2007, ss. 25-60. 
Gider, Mahmut, "Keyif Verici Maddelerden Uzak Durmanın Gerekliliği: Sünbülzâde Vehbî’nin Lutfiyye Mesnevisi Örneği”, Osmanlı Mirası Araştırmaları Dergisi, C. 6, S. 14, Mart 2019, ss. 23-35.

Gümüşçü, Ahmet ve Gümüşçü, Osman, “Türkiye'de Haşhaş ve Haşhaş Tarımının Coğrafi Dağılışı", A.Ü. Türkiye Coğrafya Araştırma ve Uygulama Merkezi Dergisi, S. 6, Ankara 1997, ss. $123-148$.

Hamarneh, Sami, "Pharmacy in Medieval Islam and the History of Drug Addiction”, Medical History, Volume: 16, Issue: 3, 1972, pp. 226-237.

Kala, Ahmet, “Esnaf”, İslam Ansiklopedisi, C. 11, TDV Yay., İstanbul 1995, ss. 423-430.

K1lıç, Rüya, “'Afyonun Keyfini Tiryakisinden Sormalı': Osmanlı ve Erken Cumhuriyet'te Madde Bağımlılığı Tarihi”, Kebikeç, S. 42, 2016, s. ss. 147-179.

Kocacık, Eyüp Talha ve Mat, Afife, "İstanbul'da Zehirler ve Zehirlenme Vakaları", Osmanlı Bilimi Araştırmaları, XV/2, 2014, ss. 21-38.

Koçu, Reşad Ekrem, “Afiyoncular, Afiyon Tiryakiliği Yasağı”, İstanbul Ansiklopedisi, C. 1, İstanbul 1958, ss. 228-229.

Mat, Afife, "Osmanlı İmparatorluğu'nda Afyonun Tarihi”, Osmanlı Bilimi Araştırmaları, XI/ 12, 2009-2010, ss. 285-290.

Ortaylı, İlber "Kadı", İslam Ansiklopedisi, C. 24, TDV Yay., İstanbul 2001, ss. 69-73.

Öge, Ali, "Şeyhülislam İbn Kemal'in Fetvaları Işı̆̆ında Osmanlı İktisâdî Hayatından Bir Kesit”, İslam Hukuku Araştırmaları Dergisi, S. 16, 2010, ss. 275-298.

Özen, Şükrü, “Tütün (F1kıh)”, İslam Ansiklopedisi, C. 42, TDV Yay., İstanbul 2012, ss. 5-9.

Quataert, Donald, “The Ages of Reforms 1812-1914”, An Economic and Social History of the Ottoman Empire 1300-1914, Ed. Halil İnalckk ve Donald Quataert, Cambridge Univ. Press, 1996, ss. 759-946.

Seddon, Toby, “The Regulation of Heroin: Drug Policy and Social Change in Early TwentiethCentury Britain”, International Journal of the Sociology of Law, Volume: 35, Issue 3, September 2007, pp. 143-156.

Taşdemir, Mehmet, “Karadeniz Bölgesinde Kendir-Keten Üretimi ve Kullanım Alanları”, Türk Kültürü İncelemeleri Dergisi, S. 8, İstanbul 2003, ss. 1-24.

Taşlıgil, Nuran ve Şahin, Güven, “Tarihsel Süreçte Haşhaş ve Afyon”, Tarih Okulu Dergisi, S. XXXIV, Haziran 2018, ss. 163-196.

Türkay, Cevdet, "Osmanlı İmparatorluğunda Yasaklar, Esrar Yasağı”, Belgelerle Türk Tarihi Dergisi, C. XI, S. 64, 1973.

Uluskan, Murat, "İstanbul'da Bir Afyonlu Macun İşletmesi: Berş-i Rahîkî Macunhanesi (17831831)”, Türk Kültürü Incelemeleri Dergisi, S. 29, İstanbul 2013, ss. 77-106.

Yaşar, Ahmet, “'Külliyen Ref’ten 'İbreten Li'l-Ğayr'e: Erken Modern Osmanlı'da Kahvehane Yasaklamaları”, Osmanlı Kahvehaneleri: Mekân, Sosyalleşme, İktidar, ed. Ahmet Yaşar, Kitap Yay., İstanbul 2010, ss. 37-47. 


\section{Summary}

Drugs attract attention as a multidimensional concept that closely affects people and societies. The multidimensional nature of narcotic drugs naturally causes this concept to be of interest to many branches of science. However, although drugs have entered the field of interest of many disciplines, the medical perspective has been important in the evaluation process of the concept as it primarily concerns human health. At this point, although it causes addiction when used for pleasure and negatively affects the mental and physical structure of the person, the role of drugs in the treatment has prevented the banning of drugs completely since ancient times.

In the Turkish-Islamic civilizations as in ancient civilizations, the sources of drugs were poppy and hemp plants and this situation continued with the Ottoman society. Among the plants that constitute the source of drugs in the Ottoman society, especially the poppy and hemp plants were applied primarily in the field of medicine. Among these, marijuana and marijuana mixtures obtained from cannabis, as well as opium and opium mixtures obtained from poppy, were widely used in treatment because they act as a softener for various pain relief and ailments such as cough.

In the Ottoman society, substances with narcotic properties were tried to be supplied in the market by the tradesmen group, which operated under the herbalists group according to the tradesmen's order. The public's need for health and healing products played a determining role in granting the right to sell to the relevant tradesmen. For this reason, the relevant tradesmen were allowed to sell substances with narcotic properties in the market only as health products. However, despite the regulations, it has been observed that some tradesmen sell goods to people who use drugs for pleasure. Upon understanding this situation, it was determined from various archive documents that the state was involved in the problem and inspected the market through tradesmen known as supply centers.

In the Ottoman Period, opium and cannabis were among the main items used for pleasure other than tobacco, and the addicted to these substances was called "tiryaki (addicts)". In the Ottoman Classical Period, tiryakiler (addicts) tried to buy drugs in certain places and the "Tiryakiler Bazaar" in Süleymaniye in Istanbul attracted attention. The tradesmen here were listed separately as "seller of opium" and "seller of cannabis" in accordance with the Ottoman tradesmen system. These shops located in the Tiryakiler Bazaar (Smokers Bazaar) were selling opium and cannabis as health products, since they were affiliated with the herbalist tradesmen. However, it was seen that they did not comply with this rule from time to time, that is, they sold goods without permission, apart from their real purpose.

Opium and cannabis, which are the sources of drugs used for pleasure other than medical reasons in the Ottoman society, could be obtained easily with the effect of the convenience of supply, although they were not reflected in the general public. Therefore, starting from the Ottoman Classical Period until the last moments of the Ottoman Empire, opium, opium pastes and syrups and cannabis derivatives had a use in order to cheer up and get away from some problems.

One of the striking points in the use of drugs for pleasure in the Ottomans is that addicts did not use drugs in public areas. It was understood that especially addicts used drugs in secret, mostly in coffee houses, and when it was realized that they were users, they lost their social and economic prestige significantly. Therefore, it is observed that drug addicts in Ottoman society were excluded in social and economic life. As a matter of fact, poets, thinkers, and clergy who had an impact on the Ottoman state and social life gave advice to the society by describing the exemplary situations that those who used opium and marijuana for pleasure. Accordingly, it was emphasized by poets, thinkers and clergy that substance use would cause religious, moral, physical and spiritual problems, and it was recommended that the state and society should struggle with substance use together. 
Drug use in the Ottomans was an inconvenient situation from the point of view of the state as well as the society. Because, according to Ottoman law, which derives its source from Islamic law, the use of substances was accepted as haram and this enabled the state to be involved in the event from a legal and administrative perspective. At this point, accepting the problem as a legal issue enabled the judicial and administrative units to take an active part in the process. In addition, the social and economic dimensions of drug use made it necessary for the relevant units of the state to deal with the issue from a broad perspective. Therefore, the problem of drug use in the Ottoman Empire has been evaluated as a multi-dimensional area that must be tackled by the state.

Another important issue regarding drugs is the developments in the world in the 19th century. Especially in the West towards the end of the 19th century, the realization of the addictive feature of new synthetic drugs has made substance addiction a subject of modern medicine. As a result, drug addiction has started to be considered as a disease that needs to be treated. This situation remained valid for the Ottoman society as well. As a matter of fact, it has started to be emphasized more in the last period of the 19th century that various cognitive and physiological problems such as perception problems, memory disorders, dizziness and weakness are caused by the use of opium and cannabis (marijuana) and synthetics derived from them. As a matter of fact, according to the information obtained from Ottoman archive sources, it was stated that many people who were thought to have mental problems actually suffered from using other drugs such as heroin, cocaine and morphine, especially marijuana. In order to prevent this, the supervisory role of the state was emphasized.

As can be seen in this study, it was noteworthy that during both the Ottoman Classical Period and the Ottoman Renovation Period, the state carried out struggle activities in the fields of judicial-administrative, economic and healthcare and applied to serious sanctions against the use of drugs for pleasure. In order to set an example for the situation, considering the possibility of drug users to adapt others to drugs, it was seen that starting from legally condemning, the state authority applied sanctions that had social and legal consequences such as imprisonment and exile. In addition, the closure of the shops of the tradesmen who were found to sell drugs for pleasure, the seizure of their goods, the fact that drugs were not sold or used in pharmacies other than a doctor's prescription, demonstrated the efforts of the state in different fields and scales.

The state's policies of struggle against the use of drugs for the purpose of pleasure have shown themselves in many areas until the last days of the Ottoman Empire, which has been valid since the Ottoman Classic Period. On the other hand, in developed countries such as America and Europe, these policies have only begun to be implemented since the late 19th century. Undoubtedly, with the developments in the pharmaceutical industry, mass production of substances such as morphine, codeine and heroin and the widespread use of these products in a pleasurable manner apart from medical purposes play a role. However, drug use in European countries dates back centuries, not only in the last period of the 19th century. On the other hand, the rapid spread of new drugs in Western societies has the effect on European countries and America to take action. Therefore, drug use in European countries and America started to be seen as a public health problem only from the end of the 19th century. As a result, strict policies of struggle, including the prohibition of production, were adopted throughout the world, and the Ottoman Empire, an important opium producer, was economically negatively affected. 